University of Nebraska - Lincoln

DigitalCommons@University of Nebraska - Lincoln

Daugherty Water for Food Global Institute:

Faculty Publications

Daugherty Water for Food Global Institute

2021

\title{
Baseflow nitrate dynamics within nested watersheds of an agricultural stream in Nebraska, USA
}

Galen Richards

Troy E. Gilmore

Aaron R. Mittelstet

Tiffany Messer

Daniel D. Snow

Follow this and additional works at: https://digitalcommons.unl.edu/wffdocs

Part of the Environmental Health and Protection Commons, Environmental Monitoring Commons, Hydraulic Engineering Commons, Hydrology Commons, Natural Resource Economics Commons, Natural Resources and Conservation Commons, Natural Resources Management and Policy Commons, Sustainability Commons, and the Water Resource Management Commons

This Article is brought to you for free and open access by the Daugherty Water for Food Global Institute at DigitalCommons@University of Nebraska - Lincoln. It has been accepted for inclusion in Daugherty Water for Food Global Institute: Faculty Publications by an authorized administrator of DigitalCommons@University of Nebraska Lincoln. 


\title{
Baseflow nitrate dynamics within nested watersheds of an agricultural stream in Nebraska, USA
}

\author{
Galen Richards, ${ }^{1}$ Troy E. Gilmore, ${ }^{1,2}$ Aaron R. Mittelstet, ${ }^{1}$ \\ Tiffany L. Messer, ${ }^{3} \&$ Daniel D. Snow ${ }^{4}$
}

1 School of Natural Resources, University of Nebraska-Lincoln, 101 Hardin Hall, Lincoln, NE 68583-0961, USA

2 Biological Systems Engineering, University of Nebraska-Lincoln, 223 L.W. Chase Hall, P.O. Box 830726, Lincoln, NE 68583-0726, USA

3 Biosystems and Agricultural Engineering, University of Kentucky,

128 C.E. Barnhart, Lexington, KY 40546-0276, USA

4 Water Sciences Laboratory, East Campus, University of Nebraska-Lincoln, 1840 N. 37th Street, Lincoln, NE 68583-0844, USA

Corresponding author - T. E. Gilmore, School of Natural Resources, University of Nebraska-Lincoln, 603 Hardin Hall, Lincoln, NE 68583-0961, USA.

Email gilmore@unl.edu

\begin{abstract}
There is a need to evaluate high surface nitrate concentrations across agricultural watersheds, both spatially and temporally, to increase understanding of source and timing of nitrogen loads in streams and rivers. Bazile Creek is a high-nitrate stream originating in the agriculturally intensive Bazile Groundwater Management Area of Eastern Nebraska, USA. It is a gaining stream that receives groundwater with high nitrate concentrations originating from nonpoint sources. The objective of this study was to determine spatial and temporal variability of baseflow nitrate concentrations in Bazile Creek and its tributaries and to relate this variability to watershed characteristics.
\end{abstract}

Published in Agriculture, Ecosystems and Environment 308 (2021) 107223

doi:10.1016/j.agee.2020.107223

Copyright /C 2020 Elsevier B.V. Used by permission.

Submitted 8 June 2020; revised 20 October 2020; accepted 22 October 2020; published 7

December 2020. 
Surface-water nitrate samples were collected monthly from July 2018 through September 2019 from nine sites in the watershed and were analyzed for nitrate concentration. Average surface water nitrate- $\mathrm{N}$ concentrations within the watershed ranged from 2.7 to $15 \mathrm{mg} \mathrm{L}^{-1}$ and were significantly different between the sites $(\mathrm{p}<0.05)$. Surface water nitrate- $\mathrm{N}$ concentrations varied seasonally in the main channel, recording the highest concentrations in winter (December-February, average $=14.4 \mathrm{mg} \mathrm{L}^{-1}$ ) when the discharge was minimum. High nitrate- $\mathrm{N}$ concentrations were observed in two of the five sampled tributaries, suggesting steady inputs of high-nitrate groundwater. The results of this study reveal substantial spatial variation in surface-water nitrate concentrations in the headwaters despite the close proximity of sampling sites. This study demonstrates that sampling tributaries along with the main channel of a stream is beneficial in determining nitrate inputs, variability and overall contaminant loading to a watershed.

Keywords: Baseflow nitrate-N, Groundwater, Seasonality, Non-point source pollution

\section{Introduction}

Surface water and groundwater nitrate concentrations have been increasing globally due to the increased use of synthetic fertilizers in the second half of the 20th century (Mitsch et al., 2001; Almasri and Kaluarachchi, 2004; Burt et al., 2010; Shukla and Saxena, 2018). In extreme cases, the ingestion of water high in nitrate leads to methemoglobinemia in young children (Shearer et al., 1972). Recent studies have linked nitrate to increased risk of developing certain types of cancers (Ward et al., 2018; Temkin et al., 2019) and the occurrence of NonHodgkin lymphoma when mixed with atrazine (Rhoades et al., 2013). Once in surface water, nitrate is transported into lakes, reservoirs, and oceans, where it contributes to eutrophication and algal blooms, causing hypoxia (Mitsch et al., 2001; Richardson et al., 2004; Desmit et al., 2018). Because of the complex nature of nitrogen inputs, projects focusing on the distribution and sources (e.g., groundwater) of surface water nitrate inputs within watersheds can help identify and better understand these inputs and dynamics of nitrate in surface water. In turn, this knowledge will lead to better identification of Best Management Practices (BMPs), and more effective BMP placement within these watersheds.

Observations of seasonal variability in surface water nitrate concentrations (e.g., Lindsey et al., 1997; Randall and Mulla, 2001; Almasri and Kaluarachchi, 2004) have provided insight into the most important pro- 
cesses governing nitrate delivery to streams. Variations in stream concentrations are impacted by several factors, including timing of precipitation (Nangia et al., 2010), seasonal fertilizer application (Kohl et al., 1971; Jaynes et al., 2001; Sorando et al., 2019), and nitrate in discharging groundwater (Lyndsey et al., 1997; Molenat et al., 2008; Miller et al., 2016). These factors control the timing of peak stream water nitrate within watersheds, with some relating maximum concentrations during storm events and others finding nitrate concentrations are inversely related to flow. Temporal changes in nitrate concentrations among different watersheds often result in inconsistent nutrient delivery to downstream water bodies, complicating management strategies across multiple watersheds (Van Meter and Basu, 2017).

Nitrate in surface water and groundwater originates from many sources including commercial fertilizers (Cao et al., 2018), animal or septic waste (Jones et al., 2019; Yang et al., 2019), erosion of minerals in geologic deposits (Böhlke et al., 1997), and/or deposition from the atmosphere (Junge, 1958; Vega et al., 2019). Analysis of local land use along with frequent surface water sampling throughout the target watersheds provides information on source and spatial concentration changes (Wang et al., 2017). Characterization of land use with intensive sampling leads to the ability to see the entire picture of nitrate delivery and transport (Steinheimer et al., 1998; Sudduth et al., 2013), allowing for the development of effective management strategies.

Watershed characteristics often dictate differences in surface water quality (Jarvie et al., 2002; Mittelstet et al., 2019). For example, soil properties affect leaching and runoff rates (Duley and Kelly, 1939; Patle et al., 2019), and underlying geology dictates groundwater movement through the aquifer and discharge to streams (Böhlke and Denver, 1995; Eidem et al., 1999; Kaandorp et al., 2018). Equally important is watershed land use, which strongly influences both ground and surface water quality (Smart et al., 1981; Scanlon et al., 2005). In watersheds where agricultural land use is predominant, excess fertilizer applied to fields and manure from livestock are often transported into nearby streams via overland or subsurface (including groundwater) flow paths (Meinardi et al., 1995; Mueller et al., 1997; Browne and Guldan, 2005; Tesoriero et al., 2013). Watershed catchment area must be considered as well. Smaller watersheds may export stormwater more rapidly, impacting trends in runoff-derived surface water quality (Black, 1997). 
Investigations into changing surface water nitrate concentrations over time is not new, especially in the Midwest where elevated concentrations have been detected since the second half of the 20th century. Research topics have included the investigation between nitrate concentration and watershed land use (Smart et al., 1981; Niño de Guzmán et al., 2012), nitrate movement through the vadose zone (Meinardi et al., 1995; Steinheimer et al., 1998), and variable nitrate input concentrations over time in small watersheds (Schilling and Wolter, 2001; Alexander et al., 2007; Stelzer et al., 2011; Jones et al., 2018). These studies all report low ( $<10 \mathrm{mg} \mathrm{L}^{-1}$ nitrate- $\mathrm{N}$ ) contributions of baseflow nitrate and sampling was focused in the main channel. Because of the complexity of agriculturally-intensive watersheds, there is a need to evaluate the spatial and temporal variability of stream nitrate at baseflow and contributions from tributaries with high surface and groundwater nitrate levels.

The objectives of this paper were to investigate spatial and temporal variability in surface water nitrate concentrations during baseflow and runoff conditions within the headwaters of Bazile Creek, a gaining agricultural stream. Nitrate samples collected near the mouth of Bazile Creek in 2010 and 2016 showed nitrate-N concentrations increased on average from 5.5 to $7.4 \mathrm{mg} \mathrm{L}^{-1}$ over that time period (Nebraska Department of Environment and Energy, 2019), highlighting the need to investigate nitrate transport and seasonality within the watershed. Additionally, baseflow nitrate-N concentrations in Bazile Creek are known to surpass $10 \mathrm{mg} \mathrm{L}^{-1}$, and underlying groundwater nitrate- $\mathrm{N}$ concentrations are reported to be around $15 \mathrm{mg} \mathrm{L}^{-1}$ (University of NebraskaLincoln, 2000). In order to better understand nitrate dynamics, surface water sampling was carried out over a 15-month period. Sampling sites were located on the main channel and tributaries. Sub-watershed land use, soils, and groundwater nitrate characteristics were then used to explain differences in nitrate concentrations between sites and over time.

\section{Methods}

\subsection{Study area}

The study was conducted within the headwaters of the Bazile Creek watershed in Northeast Nebraska (Fig. 1). Bazile Creek flows roughly northward where it enters the Missouri River upstream of the Lewis and 


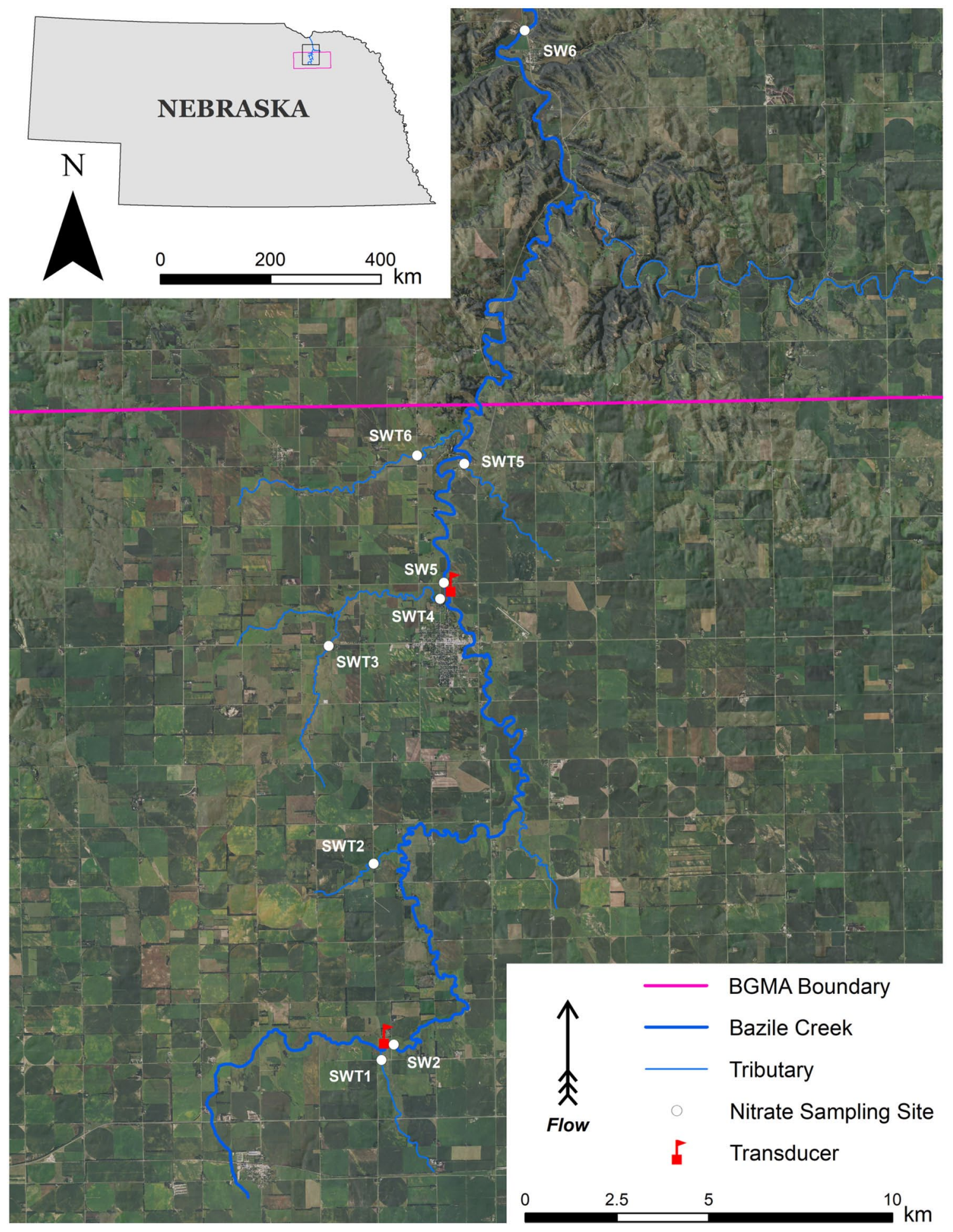

Fig. 1. Overview map of the Bazile Creek headwaters in Northeast Nebraska, including tributaries and the northern boundary of the Bazile Groundwater Management Area (BGMA). Surface water nitrate sampling sites and transducer locations are also shown. USGS gauging station 06466400 is located at site SW6. Satellite imagery from 2014. 

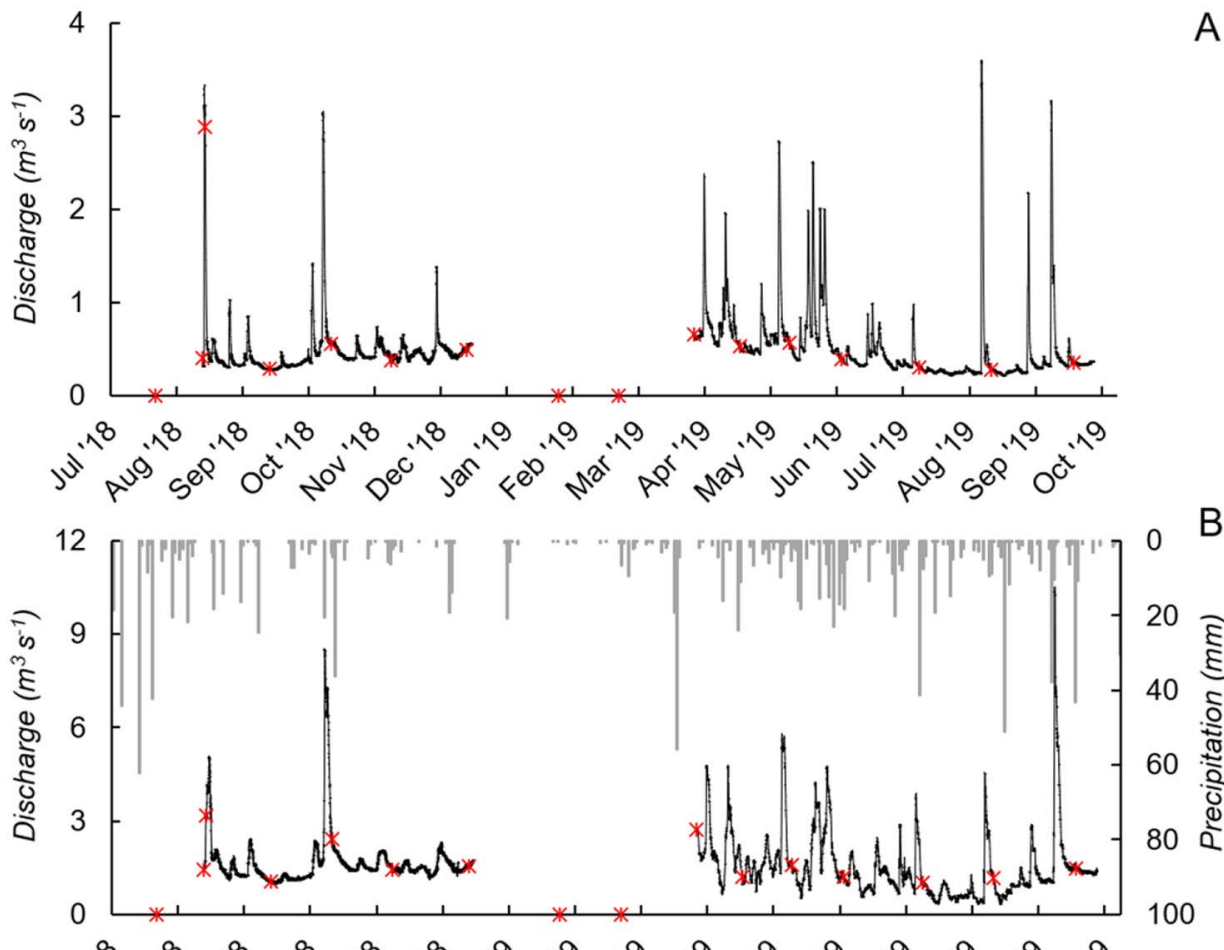

B

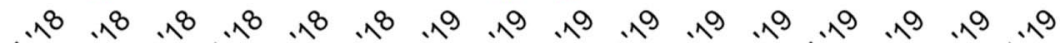

A

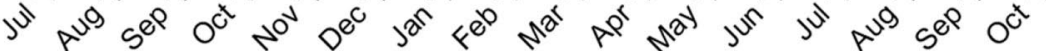

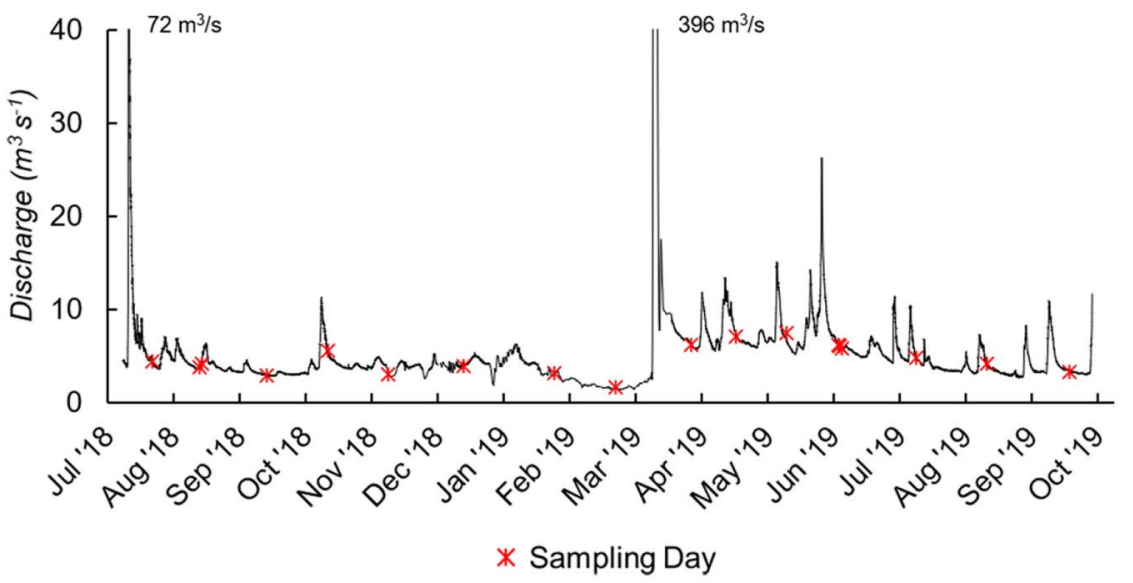

C

Fig. 2. Discharge on Bazile Creek at the SW2 transducer (A), SW5 transducer (B), and UGSG gauging station at SW6 (C). Sampling days are shown as red markers. Local precipitation is included in B. Data gaps for A and B were due to transducers being removed from the streams. Maximum discharge values are explicitly given for $\mathrm{C}$ where the peaks extend beyond the y-axis range.

Clark Reservoir. The study area received about $132 \mathrm{~cm}$ of precipitation from July 2018 through September 2019, the majority of which fell during summer months (June-August, Fig. 2). Nitrate concentrations within 
the study area have been increasing since the 1980s (Exner et al., 2014). Public supply wells for the City of Creighton, the largest town within the study area (population: 1,200, www.censusreporter.org), first exceeded the Environmental Protection Agency (EPA) nitrate-N maximum contaminant level of $10 \mathrm{mg} \mathrm{L}^{-1}$ in municipal drinking water in 1983, and ten years later installed a reverse-osmosis nitrate removal system (Gerlock, 2015). Portions of the study area are within Antelope, Knox, and Pierce counties. Based on county-level fertilizer sales (Nebraska Department of Environment and Energy, 2017) and U.S. Department of Agriculture (USDA) National Agricultural Statistics Service (NASS) census data from 2017 (www.nass.usda.gov), average fertilizer application rates were 200 $\mathrm{kg} \mathrm{N} \mathrm{ha}^{-1}$ when calculated as total fertilizer $\mathrm{N}$ sales divided by total hectares as grain in the three counties.

The watershed drainage area at the furthest downstream sampling location was $816 \mathrm{~km}^{2}$. Soils within the study area are well or excessively well-drained. About $60 \%$ of the land cover was used for corn and soybean cultivation, and $30 \%$ for grazing pasture. The area is not heavily populated, with about $5 \%$ of the land cover being developed. The underlying aquifer is at most $90 \mathrm{~m}$ thick and decreases in thickness to the north. It is composed primarily of gravel, sand, and silt originating from the Miocene and Plio-Pleistocene epochs (Gosselin, 1991), indicating high hydraulic conductivity and transmissivity of aquifer materials.

\subsection{Water sampling and analysis}

Samples were collected from July 2018 to September 2019 (15 months). Sampling locations were named based on placement along a tributary to Bazile Creek (SWT-) or the main channel (SW-), with SW being an abbreviation for Surface Water and T indicating a tributary. Eight locations were sampled in July 2018, and nine locations were sampled from August 2018 to September 2019. SW6 was added in August 2018 to incorporate additional information from the U.S. Geological Survey (USGS) stream gauge there (Fig. 1). All but one of the sampling locations (SW6) were within the Bazile Groundwater Management Area, a 1958 $\mathrm{km}^{2}$ region approved in 2016 by the Environmental Protection Agency (EPA) to receive Clean Water Act Section 319 funding due to pervasive nitrate contamination (Nebraska Department of Environment and Energy, 2016). 
Seasonal variations of stream nitrate concentrations were grouped and defined as fall (September-November), winter (December-February), spring (March-May), and summer (June-August). The 15-month sampling period resulted in more samples collected in the summer and fall than the winter and spring seasons. Monthly samples were collected at least 20 days apart from each other so that temporal trends could be more easily evaluated. The primary sampling objective was to characterize collective baseflow conditions so that runoff effects from storm events could be minimized. This objective was met for all but the August 2018 sampling event when fieldwork was inadvertently split between two days and a rain event occurred on the night of the first day (Fig. 2).

Over the course of the study, 14 monthly surface water nitrate samples were collected from SW6 and 15 monthly samples were collected from the other eight sites. This in total amounted to 134 samples collected $([15 \cdot 8]+14=134)$. Due to fences preventing direct entry into the streams, water samples at sites SW2, SW5, SWT1, SWT2, SWT3, SWT5, and SWT6 were collected from bridges using a small submersible pump connected to tubing and lowered into the stream from the overlying bridge. Stream water was pumped from the stream for at least one minute prior to sample collection to minimize cross-contamination between streams. Sample collection at sites SW6 and SWT4 was done by entering the stream directly and collecting the water sample upstream of the sampler. All samples were collected from the thalweg of the stream.

Scintillation vials $(20 \mathrm{~mL})$ were used to store water samples. Vials were rinsed three times with sample water prior to collection, and were labeled with the location, sample type, date, time, and initials of the sampler. A $0.45 \mu \mathrm{m}$ polyethersulfone filter was affixed to a syringe and roughly $20 \mathrm{~mL}$ of filtered sample water was injected into the vial. Two drops of $9 \mathrm{~N}$ sulfuric acid were then added to the vial to lower the $\mathrm{pH}$ below 2 and the sample was placed on ice to further inhibit bacterial growth. Samples were brought back to the lab and placed in a refrigerator where they were stored at a temperature below $6{ }^{\circ} \mathrm{C}$, and analyzed within three weeks. Either during or immediately after water sample collection, an In-Situ SmarTROLL multiparameter probe (In-Situ Inc., Fort Collins $\mathrm{CO}$ ) was used to measure water temperature, $\mathrm{pH}$, specific conductivity, and dissolved oxygen. Water quality data were collected during each monthly sampling campaign, except for July 2018 and November 2018 when the probe was not working properly. 
All nitrate samples were analyzed at the University of NebraskaLincoln Water Sciences Laboratory. Nitrate concentrations were determined by the cadmium reduction method using a Seal AQ2 Discrete Analyzer (SEAL Analytical Inc., Mequon WI) and in accordance with EPA method 353.2 (United States Environmental Protection Agency, 1993). Results were reported as the concentration of $\mathrm{NO}_{3}+\mathrm{NO}_{2}-\mathrm{N}$ in $\mathrm{mg} \mathrm{L}^{-1}$, and concentrations will be referred to as nitrate- $\mathrm{N}$ for the remainder of this paper

\subsection{Groundwater nitrate interpolation}

Groundwater nitrate concentrations in the watershed were obtained from the Quality-Assessed Agrichemical Database for Nebraska Groundwater (University of Nebraska-Lincoln, 2000). To reflect current conditions and to maximize the number of data points, samples from 2010 to 2017 were evaluated. The kriging interpolation method was then carried out in ArcMap 10.7 (ESRI, 2019) using an output cell size of $500 \mathrm{~m}^{2}$ and the search radius point number set to 10 . Nitrate concentrations were separated into five concentration classes: $0-5,5-10,10-15,15-20$, and 20-25 mg L ${ }^{-1}$ nitrate-N. Kriging was chosen as the interpolation method because past research has shown that it provides reasonable groundwater pollutant concentration estimates (Rabah et al., 2011; Gong et al., 2014). When compared to other interpolation methods such as Inverse Distance Weighting (IDW) or trend surface, kriging had the advantage of using spatial autocorrelation and minimum variance (Nas and Berktay, 2010). As with any interpolation method, uncertainty in kriging interpolation is still dependent on the density and distribution of known points (Childs, 2004).

\subsection{Land use and soils}

The watershed area above each sampling location was delineated using ArcMap and a 30-meter digital elevation model (DEM). Land use data were acquired from the USDA NASS website (www.nass.usda.gov). The data used were from the year 2017, and land use types were grouped into five categories: corn, soybeans, pasture, developed, and other. Data were then clipped to the target watershed and exported to Excel for further analysis. 
Gridded Soil Survey Geographic (Soil Survey Staff, 2014) data were used to characterize soils within the study area; these data were obtained from the USDA Natural Resources Conservation Service (NRCS). Soils data were separated and classified by their three pre-defined drainage classes: excessively drained, well drained, and poorly drained. Percentages of each of the three categories were determined based on areal coverage within each watershed (Table 2).

Table 1. Surface water nitrate concentrations collected monthly from each sampling location, beginning in July of 2018 and ending in September of 2019. Locations SW2SW6 were on the main channel, and SWT1-SWT6 were on tributaries (Fig. 1).

\begin{tabular}{lrrrrrrrrr} 
& $S W 2$ & \multicolumn{1}{c}{$S W 5$} & $S W 6$ & $S W T 1$ & $S W T 2$ & $S W T 3$ & $S W T 4$ & $S W T 5$ & $S W T 6$ \\
\hline Jul '18 & 12.0 & 12.3 & \multicolumn{1}{c}{ SW } & 16.5 & 2.7 & 10.9 & 8.6 & 15.0 & 2.1 \\
Aug'18 & 8.3 & \multicolumn{1}{c}{$4.3 \mathrm{a}$} & 9.4 & 16.4 & $1.1 \mathrm{a}$ & $0.7 \mathrm{a}$ & $2.1 \mathrm{a}$ & $14.5 \mathrm{a}$ & $1.4 \mathrm{a}$ \\
Sep'18 & 10.0 & 10.3 & 7.9 & 15.3 & 2.9 & 9.5 & 7.8 & 13.4 & 2.5 \\
Oct '18 & 10.7 & 8.8 & 6.6 & 14.7 & 3.5 & 3.5 & 4.1 & 14.6 & 1.9 \\
Nov'18 & 16.6 & 11.1 & 9.0 & 16.9 & 5.8 & 6.4 & 6.1 & 15.0 & 4.2 \\
Dec'18 & 15.3 & 11.2 & 9.3 & 13.9 & 4.3 & 3.9 & 4.2 & 14.7 & 4.7 \\
Jan '19 & 18.1 & 16.1 & 11.2 & 17.9 & 7.8 & 14.5 & 11.2 & 15.0 & 6.6 \\
Feb '19 & 19.3 & 17.4 & 11.8 & 17.7 & 9.5 & 14.9 & 13.3 & 15.9 & 7.3 \\
Mar'19 & 11.5 & 9.6 & 8.2 & 16.0 & 3.4 & 3.3 & 4.0 & 15.4 & 2.4 \\
Apr'19 & 9.3 & 8.4 & 7.2 & 13.6 & 1.9 & 3.2 & 4.2 & 14.2 & 1.2 \\
May'19r & 8.9 & 7.6 & 7.4 & 15.6 & 2.2 & 4.9 & 3.1 & 14.8 & 0.5 \\
Jun '19 & 8.8 & 8.4 & 8.4 & 13.6 & 2.7 & 5.9 & 5.3 & 14.8 & 1.3 \\
Jul '19 & 8.9 & 10.1 & 7.6 & 12.8 & 2.9 & 8.0 & 6.5 & 14.5 & 1.5 \\
Aug'19 & 10.2 & 8.7 & 6.5 & 15.8 & 3.4 & 6.9 & 5.6 & 13.9 & 1.5 \\
Sep'19 & 9.0 & 8.9 & 6.8 & 13.6 & 2.8 & 7.2 & 7.3 & 12.2 & 2.1 \\
Average & 11.8 & 10.2 & 8.4 & 15.3 & 3.8 & 6.9 & 6.2 & 14.5 & 2.7 \\
SDsample & 3.7 & 3.2 & 1.6 & 1.6 & 2.3 & 4.1 & 3.0 & 0.9 & 2.0 \\
\hline
\end{tabular}

a. Samples collected during high-discharge conditions compared to other samples in this study, potentially leading to anomalously low nitrate concentrations. In August 2018 samples were collected over two days, and a rain event occurred between sampling sessions.

Table 2. Surface water sampling site watershed areas along with their respective soil drainage classes and four primary land use types as percentages of the total watershed area.

\begin{tabular}{lrccccccc} 
& $\begin{array}{r}\text { Area } \\
\mathrm{km}^{2}\end{array}$ & $\begin{array}{c}\text { Excessively } \\
\text { Drained Soils } \%\end{array}$ & $\begin{array}{c}\text { Well Drained } \\
\text { Soils } \%\end{array}$ & $\begin{array}{c}\text { Poorly Drained } \\
\text { Soils } \%\end{array}$ & $\begin{array}{c}\text { Corn } \\
\%\end{array}$ & $\begin{array}{c}\text { Soybeans } \\
\%\end{array}$ & $\begin{array}{c}\text { Pasture } \\
\%\end{array}$ & \multicolumn{2}{c}{$\begin{array}{c}\text { Developed } \\
\%\end{array}$} \\
\hline SW2 & 81 & 59 & 36 & 5 & 45 & 32 & 12 & 6 \\
SW5 & 258 & 39 & 50 & 11 & 41 & 28 & 19 & 6 \\
SW6 & 816 & 17 & 77 & 6 & 33 & 24 & 34 & 5 \\
SWT1 & 11 & 34 & 64 & 2 & 61 & 18 & 10 & 5 \\
SWT2 & 7 & 54 & 43 & 3 & 49 & 28 & 15 & 4 \\
SWT3 & 22 & 44 & 37 & 19 & 35 & 22 & 34 & 4 \\
SWT4 & 45 & 35 & 50 & 15 & 32 & 20 & 33 & 6 \\
SWT5 & 21 & 24 & 76 & 0 & 47 & 29 & 13 & 5 \\
SWT6 & 17 & 11 & 83 & 6 & 29 & 24 & 28 & 6 \\
\hline
\end{tabular}




\subsection{Discharge and precipitation}

A gauging station (06466400) is maintained by the USGS on Bazile Creek at site SW6 (Fig. 1). Discharge data during the sampling period were downloaded from http://waterdata.usgs.gov. Since no other discharge data were available on Bazile Creek, HOBO U20L-04 (Onset Computer Corporation, Bourne MA) pressure transducers were installed in Bazile Creek just upstream of SW2 and SW5 (Fig. 1). After the transducers were removed from the stream, data were downloaded and converted from pressure to water depth. A third transducer was placed at SW2 in open air to record the barometric pressure, allowing for stream pressure values to be adjusted for changes in barometric pressure. Transducers were not deployed from December 17th, 2018 until March 30th, 2019 due to the presence of ice interfering with measurements.

Discharge was measured four times at the two transducer locations using a SonTek FlowTracker Acoustic Doppler Velocimeter: August 15th and December 17th, 2018 and August 22nd and December 18th, 2019. In order to calculate discharge from stream depth transducer data, a rating curve was required. Since the four discharge measurements were not sufficient, an alternative method was applied. Discharge at the upstream and downstream transducer sites were back calculated using Manning's Equation for velocity in open-channel flow

$$
\begin{gathered}
Q=A V \\
V=\frac{1}{n} R_{h}^{2 / 3} S^{1 / 2}
\end{gathered}
$$

where $Q$ is the stream discharge $\left(\mathrm{m}^{3} \mathrm{~s}^{-1}\right), A$ is the cross sectional area of flow $\left(\mathrm{m}^{2}\right), V$ is the velocity of flow $\left(\mathrm{m} \mathrm{s}^{-1}\right), n$ is Manning's coefficient of roughness, $R_{h}$ is the hydraulic radius (m), and $S$ is the water surface slope $\left(\mathrm{m} \mathrm{m}^{-1}\right)$.

Stream slope was determined using USGS topographic maps downloaded from The National Map (https://www.usgs.gov/core-sciencesystems/ngp/tnm-delivery/) and calculated as the change in elevation divided by the change in stream distance. The cross-sectional area of flow was calculated based on cross sectional channel surveys conducted on August 22, 2019. Based on cross sections observed during stream discharge measurements, the channel at the two transducer sites did not change substantially over the course of the study. For this reason, only 
the higher resolution cross-section from August 2019 was used for discharge calculations. The Manning's n value used for each site was the average of the four values obtained by measuring discharge in-situ. The upstream transducer site had an average Manning's n value of 0.063 and the downstream site had an average value of 0.035 , which were reasonable given channel types and published USGS guidelines (Arcement and Schneider, 1989). Instantaneous discharge was then calculated for 15 water depths, making sure to include the entire range of water depths (0.3-1.7 $\mathrm{m}$ for the upstream transducer and 0.3-1.5 $\mathrm{m}$ for the downstream transducer). Calculated discharge measurements were fit to a power function and rating curve equations were obtained. The equations were $y=5.92 x^{1.77}\left(R^{2}=0.998\right)$ and $y=15.74 x^{2.03}\left(R^{2}=0.996\right)$ for the upstream and downstream transducers, respectively. The equations were then used to calculate discharge for every transducer depth measurement, and the four FlowTracker discharge measurements at each site were used to validate the rating curve equations.

Precipitation data (daily) were downloaded from PRISM using the latitude/longitude coordinates $42.4722,-97.9053$ at a spatial resolution of four kilometers (PRISM Climate Group, 2004). Hydrographs for the transducer locations, USGS gauging station, and daily precipitation over the study period are shown in Fig. 2.

\subsection{Statistics}

All statistical analysis was performed in $\mathrm{R}$ version 3.5.1 (R Core Team, 2018). When running ANOVA, surface water nitrate data for each site were first log-normalized and verified to be normally distributed using the Shapiro-Wilk test. Tukey's post-hoc test was then used to make comparisons between sites. Results meeting or exceeding the $95 \%$ confidence interval were considered to be statistically significant. Pearson's correlation values were determined using the correlation function within the 'agricolae' package in R (https://CRAN.R-project. org/ package=agricolae). Outliers for the plot of average surface water nitrate-N at each sampling site versus percent land cover as corn or soybeans (Fig. 4) were detected using the aq.plot function within the package "mvoutlier" (Filzmoser et al., 2005). Points were marked as outliers if they exceeded the $97.5 \%$ quantile of the chi-squared distribution, plotted as the cumulative probability versus the ordered squared Mahalanobis distance of each point. 


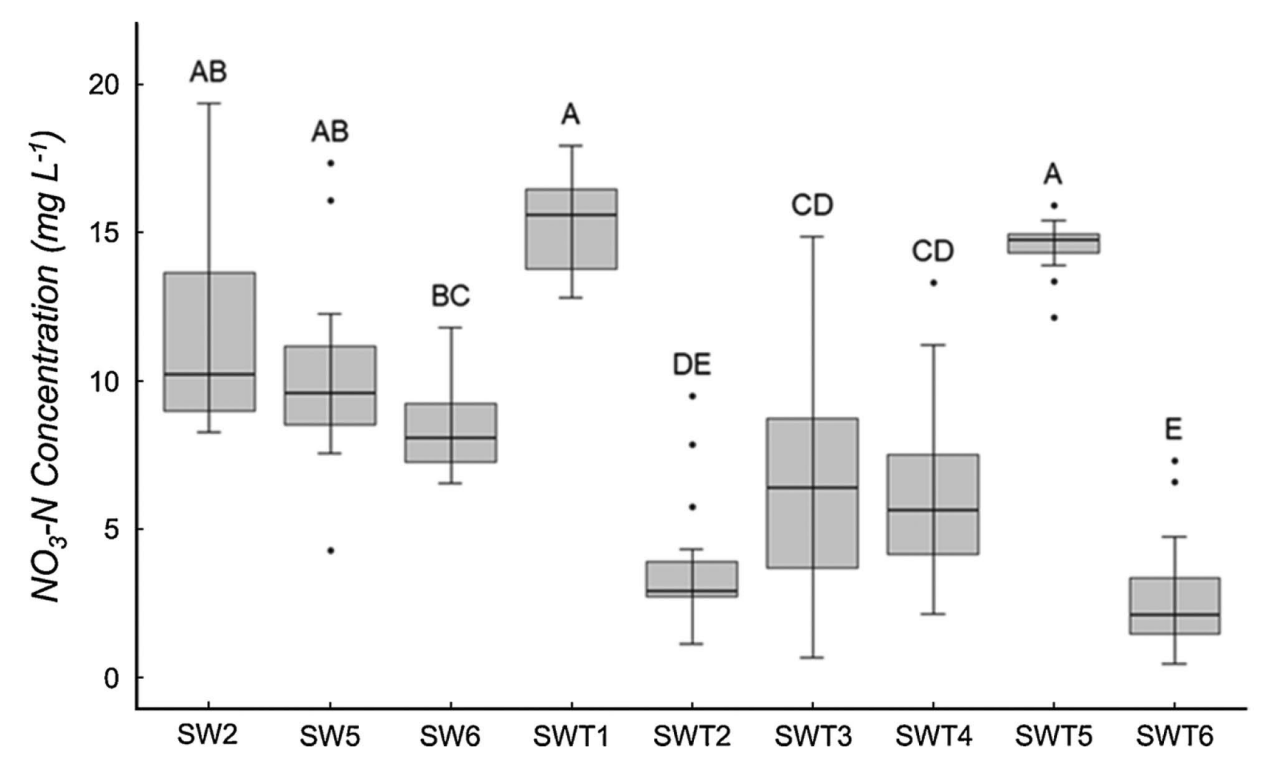

Fig. 3. Box plot showing nitrate-N concentrations for each of the surface water sites that were sampled monthly. Sites that do not share a letter were found to be significantly different from each other at the $95 \%$ confidence level according to Tukey's post-hoc range test.

\section{Results and discussion}

\subsection{Surface water nitrate dynamics}

The average nitrate- $\mathrm{N}$ concentration at each of the nine sampling sites over the duration of the study ranged from $3.8 \mathrm{mg} \mathrm{L}^{-1}$ to $15 \mathrm{mg} \mathrm{L}^{-1}$, with sites on Bazile Creek showing that nitrate concentrations decreased in the downstream direction (Fig. 3, Table 1, Figs. A1, A2). Statistical analysis of all surface water nitrate concentrations at each site showed significant variability between sites. Five statistically different groups were differentiated at the $95 \%$ confidence level among the nine sampling sites (A through E, Fig. 3).

Average winter nitrate- $\mathrm{N}$ concentrations in Bazile Creek $\left(14.4 \mathrm{mg} \mathrm{L}^{-1}\right)$ were statistically greater than those collected during the other three seasons $\left(\mathrm{p}<0.01\right.$, spring average $=8.7 \mathrm{mg} \mathrm{L}^{-1}$, summer average $=8.8 \mathrm{mg} \mathrm{L}^{-1}$, fall average $=9.6 \mathrm{mg} \mathrm{L}^{-1}$ ). The mean surface water nitrate- $\mathrm{N}$ concentrations for non-winter seasons were not statistically different $(p>0.6)$. A negative correlation was found between nitrate concentration versus discharge at site SW6 $(R=-0.67, n=14, p=0.009)$ (Supplementary Fig. 
A4). This indicates that nitrate was primarily delivered to the stream through groundwater discharge. This nitrate concentration-discharge relationship was consistent with a Nebraska Department of Environment and Energy study on Bazile Creek within the study area, where nitrate concentrations were also found to be negatively correlated with discharge (Nebraska Department of Environment and Energy, 2016). In contrast, a positive correlation between nitrate concentration and discharge would have suggested nitrate delivery from runoff, or minimal streambed denitrification (Angier and McCarty, 2008).

Temporal and spatial changes in biological nitrate transformation likely occurred during the study period but were difficult to evaluate by measuring seasonal nitrate concentration differences alone in the Bazile Creek watershed. The relationship between elevated baseflow nitrate stream concentrations in Bazile Creek are similar to that reported in a study on Emmons Creek in the Central Sand Ridges of Wisconsin (Stelzer et al., 2011). The greatest nitrate- $\mathrm{N}$ concentration differences on Emmons Creek were seen between the winter and summer and were only at most $1 \mathrm{mg} \mathrm{L}^{-1}$. This concentration range was about $44 \%$ of the average surface water nitrate concentration of $2.25 \mathrm{mg} \mathrm{L}^{-1}$. Comparatively, the average nitrate- $\mathrm{N}$ concentration difference on Bazile Creek between the winter and summer was $5.6 \mathrm{mg} \mathrm{L}^{-1}$, which was $55 \%$ of the average Bazile Creek nitrate concentration of $10.2 \mathrm{mg} \mathrm{L}^{-1}$. The lower nitrate concentrations in the spring, summer, and fall on Emmons Creek were attributed to higher streambed denitrification rates due to warmer temperatures, however this may not have been the case on Bazile Creek due to its much greater average nitrate- $\mathrm{N}$ concentration. Past research has found that denitrification was unable to remove significant quantities of nitrogen from low-order agricultural streams with high surface water nitrate- $\mathrm{N}$ concentrations. For instance, a study on denitrification rates within five low-order agricultural streams in east-central Illinois found no relationship between denitrification rate and surface water nitrate concentration (Royer et al., 2004). Another study carried out on a fourth-order agricultural stream in Iowa found nitrate-N reductions to only be about $0.11 \mathrm{mg} \mathrm{L}^{-1} \mathrm{~km}^{-1}$, with $11 \%$ attributed to biological uptake (Jones et al., 2018). If groundwater discharge is delivering the majority of the nitrate to Bazile Creek, the lower nitrate concentrations in the spring may have been more related to dilution than denitrification. High groundwater discharge rates within the Bazile Creek watershed 
could further act to reduce denitrification rates, as was the case in another Nebraska stream (Puckett et al., 2008).

Significant nitrate-N concentration differences were observed between sites, especially among tributaries (Fig. 3). Mean nitrate-N concentrations in tributary sampling sites were different from each other by as much as $12.6 \mathrm{mg} \mathrm{L}^{-1}$. Other studies focusing on water quality within agricultural watersheds have observed nitrate- $\mathrm{N}$ concentrations varying by more than $10 \mathrm{mg} \mathrm{L}^{-1}$ between tributaries. For example, a research study in South-Central Iowa reported that nitrate- $\mathrm{N}$ concentrations between tributaries ranged from $<0.1$ to $13 \mathrm{mg} \mathrm{L}^{-1}$ (Schilling and Wolter, 2001). However, the spatial proximity between tributaries did not necessarily result in similar nitrate concentrations. Two adjacent tributaries (SWT5 and SWT6, Fig. 1) had an average nitrate-N concentration difference of $11.8 \mathrm{mg} \mathrm{L}^{-1}$ despite the streams flowing within a few kilometers of each other (Fig. 1).

All sampling sites except for SW6 were within $17 \mathrm{~km}$ of each other. Nitrate concentration differences between sites indicate that there were factors such as land use, soil characteristics, and groundwater-surface water connectivity that varied on a small spatial scale, having a significant effect on nitrate- $\mathrm{N}$ delivery to each of the streams. Average nitrate- $\mathrm{N}$ concentrations from sampling sites on the main channel of Bazile Creek (SW2, SW5, and SW6) were not significantly different from each other, although concentrations did appear to decrease in the downstream direction.

Nitrate-N concentrations varied temporally over the study period within and between sites, especially among tributaries. The SWT2, SWT3, and SWT6 sites all had coefficients of variation (CVs) above 60\%, and tributary sites SWT1 and SWT5 had much lower CVs of $10 \%$ and $6 \%$, respectively. Bazile Creek sampling sites had CVs ranging from 19 to $32 \%$. Large differences in CVs among tributaries indicate that nitrate- $\mathrm{N}$ delivery is not consistent throughout sub-watersheds in the Bazile Creek watershed. The tributaries with the highest average nitrate- $\mathrm{N}$ concentrations also had the lowest CVs, indicating consistent delivery from a high nitrate source during baseflow conditions to those streams (Fig. A3).

It is common for agricultural watersheds to have maximum surface water nitrate- $\mathrm{N}$ concentrations in the spring or summer during high discharge events (Williams et al., 2015; Royer et al., 2004; Castillo et al., 2000). This is typically due to high runoff rates or tile drainage. Tile 
drains quickly drain fields during storm events and deliver water, high in nitrate, directly to streams (Miller et al., 2017). Tile drainage is present in the Bazile Creek watershed, primarily upstream of SW5 where the water table is especially shallow (USDA NRCS personal correspondence). Because of the predominance of well and excessively drained soils in our study area (Table 2), tile drainage density is likely low compared to other intensively drained regions of the Midwest (based on 2012 data; Nakagaki and Wieczorek, 2016). The use of drainage tile in the Bazile Creek watershed has increased since 2012, but the exact area of tiling installed within the watershed is unknown.

Extensive buffering is present throughout much of the Bazile Creek watershed. Approximately $75 \%$ of land area within $100 \mathrm{~m}$ of streams within the watershed were classified as pasture or forest. Precipitation rates in the area are generally greatest from the spring to the fall, and much of the runoff from fields is likely intercepted by these forest or pasture buffers before entering surface water bodies. Flow through buffers generally aids in the reduction of nitrate in runoff, thus reducing $\mathrm{N}$ loading from runoff (Patty et al., 1997; Lowrance et al., 2002; Messer et al., 2012). Research conducted in Western Iowa showed that riparian buffers can also act to reduce nitrate from discharging groundwater though nutrient uptake in the root zone (Yamada et al., 2007). At one location in Iowa, groundwater nitrate- $\mathrm{N}$ concentrations were reduced from $25 \mathrm{mg} \mathrm{L}^{-1}$ to below the quantitation limit $\left(0.3 \mathrm{mg} \mathrm{L}^{-1}\right)$ in less than three years after the installation of the buffer. For this reason, it is likely that some nitrate in groundwater discharging to streams within the Bazile Creek watershed is removed as it passes through riparian buffers. Nitrate removal however is likely to be seasonal, dependent on the buffer vegetation composition, and dependent on the soils and hydrology of the buffers.

\subsection{Precipitation and stream discharge}

Seasonal precipitation was greatest in the spring (March-May 2019) and summer (June-August 2019) with a total accumulation of 350 and $330 \mathrm{~mm}$, respectively. Winter (December 2018-February 2019) had the lowest precipitation at $90 \mathrm{~mm}$ followed by $150 \mathrm{~mm}$ in the fall (September-November 2018). Discharge at the USGS gauging station averaged $3.8 \mathrm{~m}^{3} \mathrm{~s}^{-1}$ in the fall, $4.3 \mathrm{~m}^{3} \mathrm{~s}^{-1}$ in the winter, $11 \mathrm{~m}^{3} \mathrm{~s}^{-1}$ in the spring, and $4.7 \mathrm{~m}^{3} \mathrm{~s}^{-1}$ in the summer (Fig. 2). The high mean discharge in the spring was caused largely by extreme flooding in Nebraska and 
much of the Midwest (Flanagan et al., 2020). Factors such as heavy precipitation, saturated/frozen soils overlain by snow, and frozen streams resulted in an extraordinary amount of runoff which quickly overwhelmed stream channels, levees, and dams (Bagwell and Peters, 2019). The Bazile Creek watershed was not spared from that natural disaster. Peak discharge at the USGS gauging station approached 400 $\mathrm{m}^{3} \mathrm{~s}^{-1}$ and was determined to be a 260-year flood event (Davis, 2020). This flooding likely resulted in an elevated water table within the project area for the remainder of the sampling period, which could have impacted nitrate concentrations.

Average discharge at each location during the periods when the transducers were deployed (8/15-12/17/2018, 3/30-10/01/2019) was $0.5 \mathrm{~m}^{3}$ $\mathrm{s}^{-1}$ at the SW2 transducer, $1.6 \mathrm{~m}^{3} \mathrm{~s}^{-1}$ at the SW5 transducer, and $5.0 \mathrm{~m}^{3} \mathrm{~s}^{-1}$ at SW6. Discharge at the SW5 transducer was somewhat erratic. This erratic behavior was likely due to the transducer being downstream of the City of Creighton municipal water treatment plant outfall, which periodically discharged wastewater generated during the reverse-osmosis nitrate removal process at a rate of no more than $0.004 \mathrm{~m}^{3} \mathrm{~s}^{-1}$ (K. Sonnichsen, City of Creighton Water Commissioner, personal communication, May 21, 2020).

Average discharge from March 30th to October 1st, 2019 was compared to watershed area at each of the three measurement locations. The SW2 transducer had a discharge/watershed area ratio of 0.0065 $\mathrm{m}^{3} \mathrm{~s}^{-1}$ per km $\mathrm{km}^{2}$, the SW5 transducer had a value of $0.0060 \mathrm{~m}^{3} \mathrm{~s}^{-1}$ per km $\mathrm{km}^{2}$, and the gauging station at SW6 had a value of $0.0069 \mathrm{~m}^{3} \mathrm{~s}^{-1}$ per $\mathrm{km}^{2}$. The smaller discharge/watershed area ratio for the SW5 transducer was likely due to either decreased runoff or decreased groundwater discharge to Bazile Creek relative to the other two transducer locations. Soils within the watersheds upstream of each transducer are generally poorly to well drained indicating a potential increase in runoff potential between the two transducers. The USGS gauging station, which had the largest discharge/watershed area value, likely proportionally received the most runoff. This is because much of the watershed between the SW5 transducer and the USGS gauging station lacks any substantial aquifer, potentially leading to faster water transport to streams.

\subsection{Watershed land use characteristics}

The SW6 watershed, which included all sampling locations, had a total area of $816 \mathrm{~km}^{2}$. Land use upstream of SW6 was 57\% cultivated crop- 
land, $34 \%$ pasture, and 5\% developed. Cultivated cropland (primarily of corn and soybeans) was the dominant land use type within all nine sub-watersheds, and corn consistently covered a greater extent of land area than soybeans. Pasture ranged from 10 to $34 \%$ of subwatershed land cover and increased in the downstream direction, especially downstream of SW5 where rough terrain and diminished aquifer thickness made irrigated farming difficult. All nine of the watersheds had small areas of developed land (3-6\%, Table 2).

It has been extensively reported that small-scale land use in an agricultural watershed had a direct effect on surface water quality (Young and Briggs, 2005; Schilling and Libra, 2000; Poor and McDonnell, 2007). This appeared to also be the case within the Bazile Creek watershed. Average surface water nitrate- $\mathrm{N}$ concentrations for sampling locations were positively correlated to the percentage of the sub-watershed planted with corn or soybeans (Fig. 4). Based on robust Mahalanobis distance SWT2 was determined to be an outlier. When removed, the $\mathrm{R}^{2}$

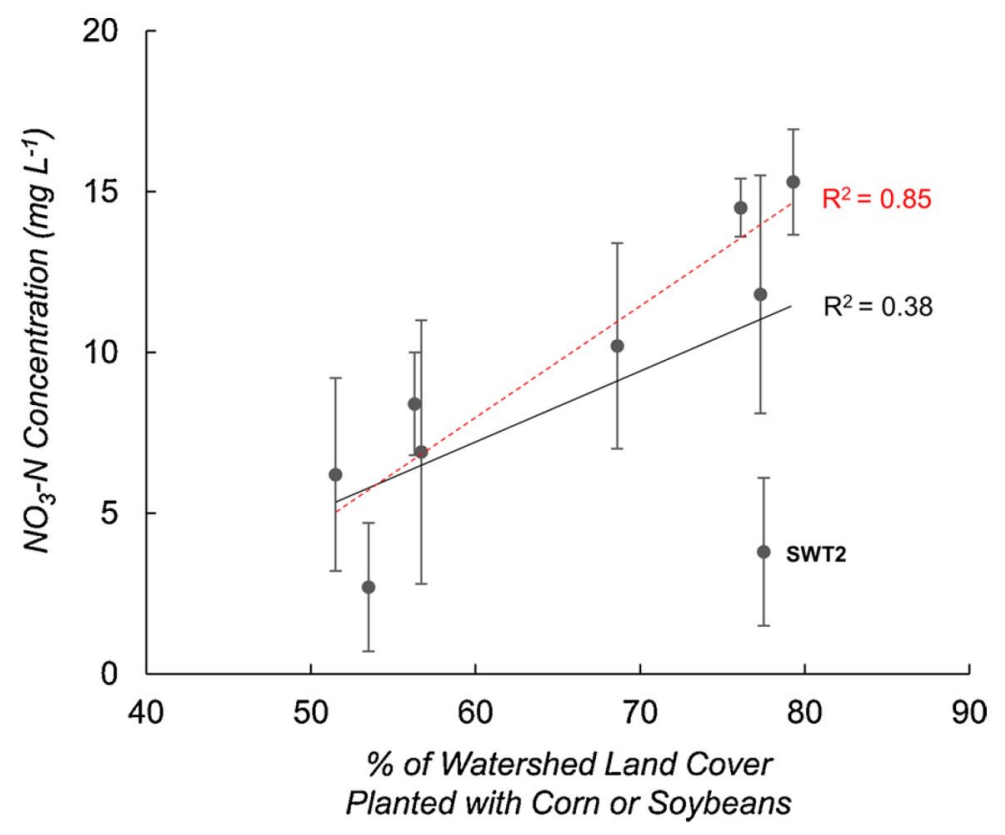

Fig. 4. Average surface water nitrate concentration at each sampling site vs. the percentage of their respective watershed area planted with corn or soybeans. Outlier SWT2 is labeled. Two trendlines are shown, with the solid (black) trendline having the equation $\mathrm{y}=0.2376 \mathrm{x}-6.886$, and the equation for the dashed (red) trendline being $y=0.3398 x-12.558$. The solid (black) line includes the outlier, and the dashed (red) line excludes it. The upper (red) and lower (black) $\mathrm{R}^{2}$ values correspond to the dashed and solid trendlines of matching colors, respectively. 
correlation coefficient increased from 0.38 to 0.85 . With the outlier included, Pearson's R was $0.62(\mathrm{p}=0.073)$, and when SWT2 was excluded $R$ increased to $0.92(p=0.0013)$.

\subsection{Groundwater quality}

In 2017, groundwater nitrate concentrations within the study area averaged $17.6 \mathrm{mg} \mathrm{L}^{-1}$ nitrate-N (University of Nebraska-Lincoln, 2000). Interpolated groundwater nitrate- $\mathrm{N}$ concentrations within the study area ranged from $<5$ to $20-25 \mathrm{mg} \mathrm{L}^{-1}$ (Fig. 5). Only a small portion of the watershed area had interpolated concentrations below $5 \mathrm{mg} \mathrm{L}^{-1}$ (Fig. 5). Concentrations between 10 and $20 \mathrm{mg} \mathrm{L}^{-1}$ were the most prevalent. The spatial density of wells decreased to the north, which resulted in higher uncertainty in interpolated nitrate- $\mathrm{N}$ concentrations in the upper quarter of the map.

Excess nitrate from nitrogen fertilizers applied to fields was transported to the streams via runoff and/or groundwater discharge, resulting in increased surface water nitrate- $\mathrm{N}$ concentrations. Based on soil drainage classes within each sub-watershed (Table 2) the majority of nitrate-N likely entered streams within the study area as groundwater discharge and not surface water runoff. This conclusion on nitrate delivery to streams is supported by Fig. 5, which showed interpolated groundwater nitrate- $\mathrm{N}$ concentrations to be in good agreement with average surface water concentrations at many of the sampling sites. In addition, estimated baseflow indices for the Bazile Creek watershed ranged from 56 at SW6 to 62 near SW2 (Wolock, 2003) indicating that streams in the watershed receive a large percentage of their flow from groundwater discharge.

The SWT2 site was an outlier, having a lower than expected surface water nitrate- $\mathrm{N}$ concentration given its watershed land use. Interpolated groundwater nitrate-N concentrations underlying the SWT2 watershed were low compared to other sites at 5-10 $\mathrm{mg} \mathrm{L}^{-1}$ (Fig. 5), and the well closest to the sampling site had groundwater nitrate- $\mathrm{N}$ concentrations in the $2-5 \mathrm{mg} \mathrm{L}^{-1}$ range. Therefore, it is possible that low-nitrate groundwater discharge is a large component of the flow at SWT2.

The SWT6 site interestingly had low surface water nitrate-N concentrations and high (20-25 mg L $\mathrm{L}^{-1}$ ) interpolated groundwater concentrations. The difference between surface water and groundwater nitrate 


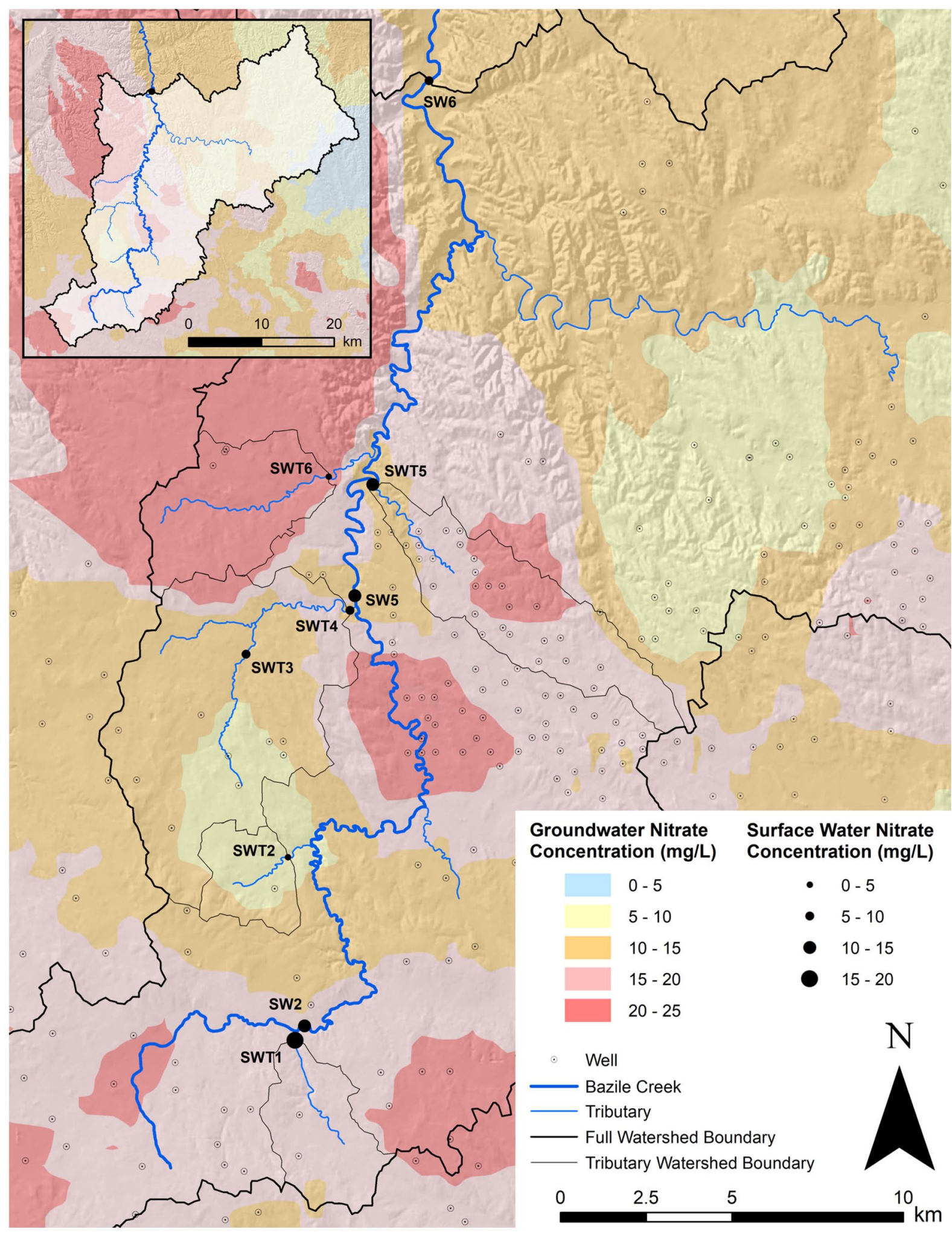


Fig. 5. Map of the study area showing interpolated groundwater and average surface water nitrate concentrations at each of the monthly sampling sites. The watershed boundary from the furthest downstream sampling site is shown, with an inset showing its full extent. The watershed boundaries of each tributary at the farthest downstream sampling location are shown as thin lines. Locations of groundwater wells used in the interpolation are also displayed.

could have been due to high uncertainty in the interpolated groundwater nitrate- $\mathrm{N}$ concentrations since there were few wells in the area. If groundwater nitrate-N concentrations within the SWT6 watershed were actually high, then the stream received minimal groundwater discharge. Elevated surface water nitrate-N concentrations at SWT6 in the winter (Table 1) suggest there is some high nitrate-N input to the stream, which was likely groundwater-derived due to minimal precipitation during that time (Fig. 2). As a comparison, SWT1 and SWT5 likely received most of their discharge from groundwater throughout the sampling period given high and consistent monthly nitrate-N concentrations, which were in close agreement with underlying interpolated groundwater values.

\subsection{Nitrate reduction strategies}

Collectively, efforts to reduce groundwater nitrate concentrations are critical for reducing nitrate concentrations in Bazile Creek, even if there are significant lag times between practice implementation and improved stream water quality (Böhlke and Denver, 1995; Stolp et al., 2010; Gilmore et al., 2016a, 2016b). Ongoing demonstration projects and agronomic research on diverse cropping rotation, soil health, and nitrogen inhibitors within the Bazile Groundwater Management Area (Lewis and Clark Natural Resources District, 2020) should be used to assist into local decision-making. In general, we note that percentages of well and excessively well-drained soils in the study area are consistent with high rates of nitrate leaching from fertilized crops. BMPs such as cover crops and split fertilizer application (e.g., as suggested by modeling in Mittelset et al. (2019)) may be considered as part of comprehensive nutrient and water management plans for managing nitrate concentrations in the Bazile Creek watershed. Groundwater nitrate- $\mathrm{N}$ concentrations in applied irrigation water can also be accounted for in nutrient budgets (e.g. using the University of Nebraska-Lincoln Corn Nitrogen Recommen- 
dations Calculator, https://cropwatch.unl.edu/soils), although this approach may involve risk due to the fact that inconsistent summer precipitation will affect yearly irrigation rates.

Given the unknown but likely substantial time lag between BMP implementation and reduced groundwater nitrate concentrations, it is important to explore additional approaches that could provide shorterterm nitrate loading reductions. For instance, engineered solutions to increase streambed denitrification rates could be investigated as a nitrate removal option. Nitrate removing bioreactors have shown promise when implemented in locations where organic carbon availability is limiting denitrification rates (Schipper et al., 2010; Fenton et al., 2016). However, a thorough investigation would be needed to determine suitable sites (including location and prevalence of subsurface drainage) within the Bazile Creek watershed for the installation of bioreactors to maximize nitrate removal. Another option for near or in-stream nitrate removal are streambed/stream modifications that improve denitrification rates by increasing hyporheic flow (Herzog et al., 2016).

In order to see substantial reductions to nitrate loads in the Bazile Creek watershed, it is likely that a combination of strategies will need to be adopted, and strategies used by past successful water quality improvement projects should be considered. For example, a project carried out in the Honey Creek watershed in Northeast Oklahoma was successful in reducing nonpoint source nitrate loading by $35 \%$ in eight years (Perez, 2017). These load reductions were obtained by installing or upgrading septic tanks, creating protective riparian buffers, increasing pasture, and improved management of animal manure. Importantly, prior to beginning the Honey Creek watershed project an adjacent control watershed was selected to quantify water quality improvements more accurately over time.

Ongoing water quality projects in the Bazile Creek watershed will investigate nitrate concentration and transit times of discharging groundwater as well as the measurement of nitrate isotopes. Understanding groundwater transit times will give information on trends between groundwater age and nitrate concentration as well as spatial differences in transit times (e.g., Gilmore et al., 2016a, 2016b). Nitrate isotopes will provide information on source and potentially seasonal enrichment due to denitrification (Panno et al., 2008; Comer-Warner et al., 2020). 


\section{Conclusions}

Nitrate concentrations in the Bazile Creek watershed were found to vary significantly between many of the sampling sites, especially between sites on tributaries. Average nitrate- $\mathrm{N}$ concentrations at each of the nine sites ranged from 2.7 to $15.3 \mathrm{mg} \mathrm{L}^{-1}$ and were at a maximum in the winter on the main channel. Land cover within the study area was primarily cropland, and there was a positive correlation between the percentage of land cover as cropland and average surface water nitrate concentrations. Extensive riparian buffering, high soils drainage classes, and interpolated groundwater nitrate- $\mathrm{N}$ concentrations falling primarily between 10 and $20 \mathrm{mg} \mathrm{L}^{-1}$ indicate that baseflow nitrate was delivered to the Bazile Creek watershed as groundwater discharge.

The combined analysis of land use, soil properties, and groundwater nitrate- $\mathrm{N}$ concentrations helped explain surface water concentration differences between sampling locations. Because nitrate entered streams through groundwater pathways, a range of BMPs focused on reducing nitrate leaching beneath agricultural fields and engineered solutions to maximize denitrification rates in and near streams may be important to consider as part of a holistic management approach.

Competing Interests The authors report no declarations of interest.

Acknowledgments Funding for this research was provided by Nebraska Department of Environment and Energy Project\# 56-1641 as well as U.S. Department of Agriculture National Institute of Food and Agriculture Hatch Project 1015698. The authors appreciate the time and effort that the anonymous reviewers have taken to improve this manuscript. We would like to thank Alan Boldt, Sydney Corcoran, Caner Zeyrek, Mikaela Cherry, and Mason Johnson for assisting with fieldwork, the Lewis and Clark, Lower Elkhorn, Lower Niobrara, and Upper Elkhorn Natural Resources Districts for their support, and the landowners who allowed us access to their property for the purposes of collecting samples and installing equipment; this research would not have been possible without their assistance.

AGEE26256_DataProfile.xml is attached to this archive record as a .zip file. 


\section{Appendix A.}
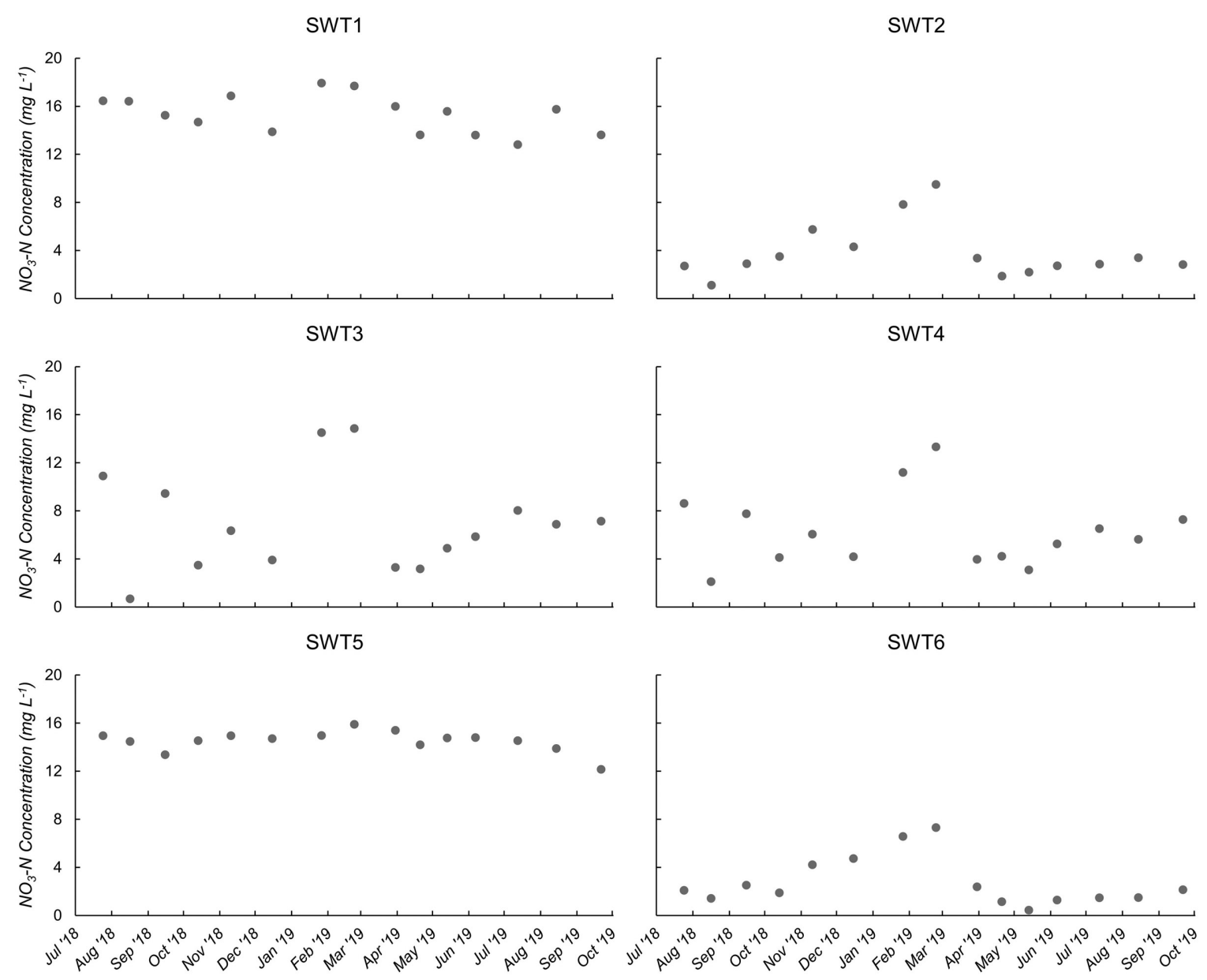

Supplementary Fig. A1. Monthly surface water nitrate-N concentrations at each of the six Bazile Creek tributary sampling locations over the course of the study. 

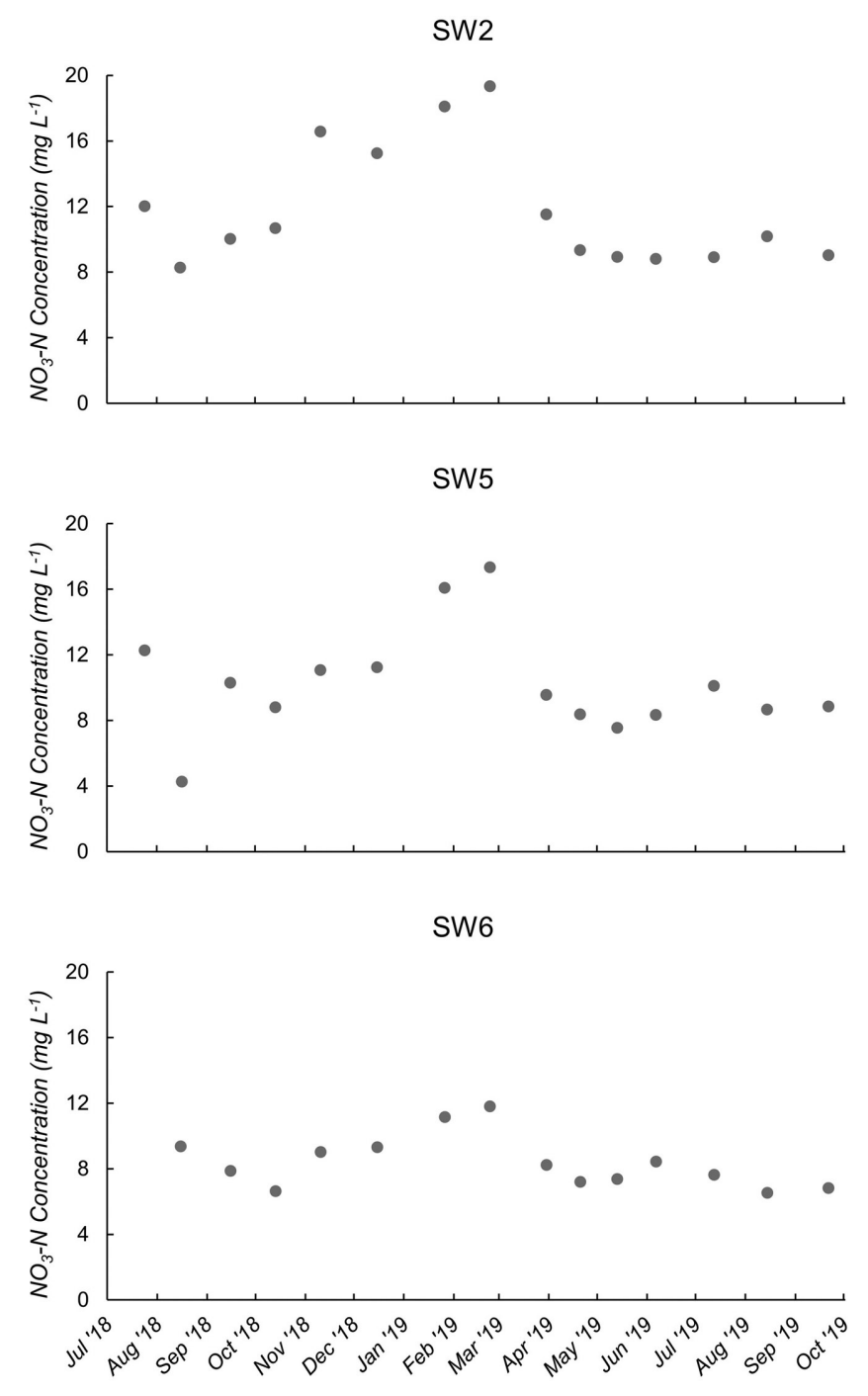

Supplementary Fig. A2. Monthly surface water nitrate-N concentrations at the three Bazile Creek sampling locations over the course of the study. 


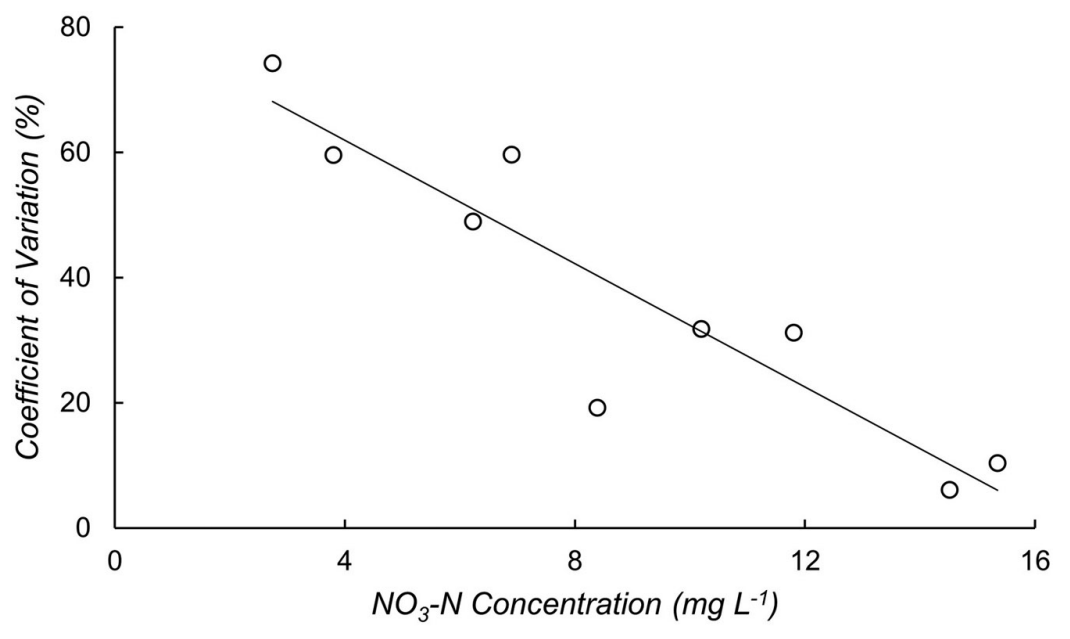

Supplementary Fig. A3. Coefficient of Variation vs. average nitrate-N concentration for each of the nine surface water sampling sites. The given trendline has a Pearson's $\mathrm{R}^{2}=0.85(\mathrm{p}<0.001)$.

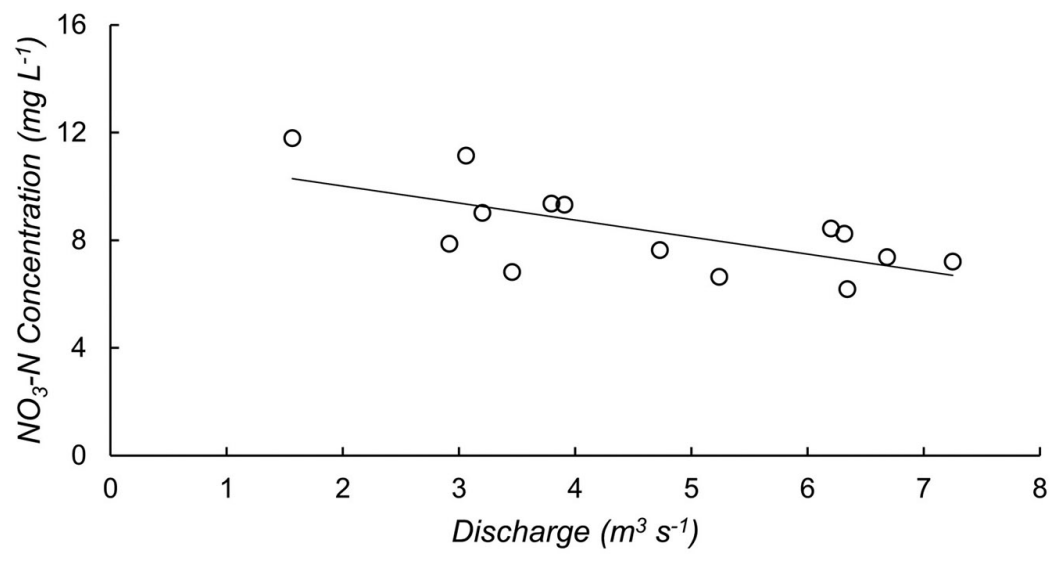

Supplementary Fig. 4. Nitrate-N concentration at SW6 vs. discharge for samples collected during the study period. The given trendline has a Pearson's $R^{2}=0.45(p=0.009)$ 


\section{References}

Alexander, R.B., Boyer, E.W., Smith, R.A., Schwarz, G.E., Moore, R.B., 2007. The role of headwater streams in downstream water quality. J. Am. Water Resour. Assoc. 43, 41-59. https://doi.org/10.1111/j.1752-1688.2007.00005.x

Almasri, M.N., Kaluarachchi, J.J., 2004. Assessment and management of long-term nitrate pollution of ground water in agriculture-dominated watersheds. J. Hydrol. 295, 225-245. https://doi.org/10.1016/i.jhydrol.2004.03.013

Angier, J.T., McCarty, G.W., 2008. Variations in base-flow nitrate flux in a first-order stream and riparian zone. J. Am. Water Resour. Assoc. 44, 367-380. https://doi. org/10.1111/j.1752-1688.2007.00153.x

Arcement, G.J., Schneider, V.R., 1989. Guide for selecting Manning's roughness coefficients for natural channels and flood plains. Water Supply Paper. https:// doi.org/10.3133/wsp2339

Bagwell, R., Peters, B., 2019. Analysis of the 2019 midwest US flooding using NASA data. American Geophysical Union, Fall Meeting 2019. https://agu.confex.com/ agu/fm19/meetingapp.cgi/Paper/519219

Black, P.E., 1997. Watershed functions. J. Am. Water Resour. Assoc. 33, 1-11.

Böhlke, J.K., Denver, J.M., 1995. Combined use of groundwater dating, chemical, and isotopic analyses to resolve the history and fate of nitrate contamination in two agricultural watersheds, Atlantic coastal plain, Maryland. Water Resour. Res. 31 (9), 2319-2339. https://doi.org/10.1029/95WR01584

Böhlke, J.K., Ericksen, G.E., Revesz, K., 1997. Stable isotope evidence for an atmospheric origin of desert nitrate deposits in northern Chile and southern California, U.S.A. Chem. Geol. 136, 135-152. https://doi.org/10.1016/ $\underline{\text { S0009-2541(96)00124-6 }}$

Browne, B.A., Guldan, N.M., 2005. Understanding long-term baseflow water quality trends using a synoptic survey of the ground water-surface water interface, Central Wisconsin. J. Environ. Qual. 34, 825-835. https://doi.org/10.2134/ jeq2004.0134

Burt, T.P., Howden, N.J.K., Worrall, F., Whelan, M.J., 2010. Long-term monitoring of river water nitrate: how much data do we need? J. Environ. Monit. 12, 71-79. https://doi.org/10.1039/b913003a

Cao, P., Lu, C., Yu, Z., 2018. Historical nitrogen fertilizer use in agricultural ecosystems of the contiguous United States during 1850-2015: application rate, timing, and fertilizer types. Earth Syst. Sci. Data 10, 969-984. https://doi. org/10.5194/essd-10-969-2018

Castillo, M.M., Allan, J.D., Brunzell, S., 2000. Nutrient concentrations and discharges in a midwestern agricultural catchment. J. Environ. Qual. 29, 1142-1151. https:// doi.org/10.2134/jeq2000.00472425002900040015x

Childs, C., 2004. Interpolating Surfaces in ArcGIS Spatial Analyst. ArcUser July- September Developer's Corner 32-35. https://www.esri.com/news/ arcuser/0704/summer2004.html 
Comer-Warner, S.A., Gooddy, D.C., Ullah, S., Glover, L., Kettridge, N., Wexler, S.K., Kaiser, J., Krause, S., 2020. Seasonal variability of sediment controls of nitrogen cycling in an agricultural stream. Biogeochemistry 148, 31-48. https://doi. org/10.1007/s10533-020-00644-z

Davis, A., 2020. Using Return Intervals and Nutrient Spiraling to Examine the 2019 Nebraska, USA Flood. University of Nebraska-Lincoln School of Natural Resources. Thesis.

Desmit, X., Thieu, V., Billen, G., Campuzano, F., Duli’ere, V., Garnier, J., Lassaletta, L., M'enesguen, A., Neves, R., Pinto, L., Silvestre, M., Sobrinho, J.L., Lacroix, G., 2018. Reducing marine eutrophication may require a paradigmatic change. Sci. Total Environ. 635, 1444-1466. https://doi.org/10.1016/j.scitotenv.2018.04.181

Duley, F.L., Kelly, L.L., 1939. Effect of Soil Type, Slope, and Surface Conditions on Intake of Water. Hist. Res. Bull. Nebraska Agric. Exp. Stn., p. 66

Eidem, J.M., Simpkins, W.W., Burkart, M.R., 1999. Geology, groundwater flow, and water quality in the walnut creek watershed. J. Environ. Qual. 28, 60-69. https:// doi.org/10.2134/jeq1999.00472425002800010006x

ESRI, 2019. ArcGIS Desktop: Release 10.7. Redlands. Environmental Systems Research Institute, CA.

Exner, M.E., Hirsh, A.J., Spalding, R.F., 2014. Nebraska's groundwater legacy: nitrate contamination beneath irrigated cropland. Water Resour. Res. 50, 4474-4489. https://doi.org/10.1002/2013WR015073

Fenton, O., Healy, M.G., Brennan, F.P., Thornton, S.F., Lanigan, G.J., Ibrahim, T.G., 2016. Holistic evaluation of field-scale denitrifying bioreactors as a basis to improve environmental sustainability. J. Environ. Qual. 45, 788-795. https://doi. org/10.2134/jeq2015.10.0500

Filzmoser, P., Garrett, R.G., Reimann, C., 2005. Multivariate outlier detection in exploration geochemistry. Comput. Geosci. 31, 579-587. https://doi. org/10.1016/j.cageo.2004.11.013

Flanagan, P.X., Mahmood, R., Umphlett, N.A., Haacker, E., Ray, C., Sorensen, W., Shulski, M., Stiles, C.J., Pearson, D., Fajman, P., 2020. A hydrometeorological assessment of the historic 2019 flood of Nebraska, Iowa, and South Dakota. Bull. Am. Meteorol. Soc. 1-31. https://doi.org/10.1175/bams-d-19-0101.1

Gerlock, G., 2015. Nitrates a Costly, Persistent Problem for Small Towns. Nebraska Educational Telecommunications Commission/ Harvest Public Media. http://netnebraska.org/article/news/995673/ nitrates-costly-persistent-problem-small-towns

Gilmore, T.E., Genereux, D.P., Solomon, D.K., Solder, J.E., Kimball, B.A., Mitasova, H., Birgand, F., 2016a. Quantifying the fate of agricultural nitrogen in an unconfined aquifer: stream-based observations at three measurement scales. Water Resour. Res. 52, 1961-1983. https://doi.org/10.1002/2015WR017599

Gilmore, T.E., Genereux, D.P., Solomon, D.K., Solder, J.E., 2016b. Groundwater transit time distribution and mean from streambed sampling in an agricultural coastal plain watershed, North Carolina, USA. Water Resour. Res. 52, 2025-2044. https:// doi.org/10.1002/2015WR017600 
Gong, G., Mattevada, S., O'Bryant, S.E., 2014. Comparison of the accuracy of kriging and IDW interpolations in estimating groundwater arsenic concentrations in Texas. Environ. Res. 130, 59-69. https://doi.org/10.1016/j.envres.2013.12.005

Gosselin, D.C., 1991. Bazile Triangle Groundwater Quality Study. Nebraska Conservation and Survey Division, p. 146.

Herzog, S.P., Higgins, C.P., Mccray, J.E., 2016. Engineered streambeds for induced hyporheic flow: enhanced removal of nutrients, pathogens, and metals from urban streams. J. Environ. Eng. 142, 1-10. https://doi.org/10.1061/(ASCE) EE.1943-7870.0001012

Jarvie, H.P., Oguchi, T., Neal, C., 2002. Exploring the linkages between river water chemistry and watershed characteristics using GIS-based catchment and locality analyses. J. Mater. Cycles Waste Manage. 3, 36-50. https://doi.org/10.1007/ $\underline{\text { s10113-001-0036-6 }}$

Jaynes, D.B., Colvin, T.S., Karlen, D.L., Cambardella, C.A., Meek, D.W., 2001. Nitrate loss in subsurface drainage as affected by nitrogen fertilizer rate. J. Environ. Qual. 30, 1305-1314. https://doi.org/10.2134/jeq2001.3041305x

Jones, C.S., Kim, Swon, Wilton, T.F., Schilling, K.E., Davis, C.A., 2018. Nitrate uptake in an agricultural stream estimated from high-frequency, in-situ sensors. Environ. Monit. Assess. 190 https://doi.org/10.1007/s10661-018-6599-1

Jones, C.S., Drake, C.W., Hruby, C.E., Schilling, K.E., Wolter, C.F., 2019. Livestock manure driving stream nitrate. Ambio 48, 1143-1153. https://doi.org/10.1007/ $\underline{\text { s13280-018-1137-5 }}$

Junge, C.E., 1958. The distribution of ammonia and nitrate in rain water over the United States. Eos, Trans. Am. Geophys. Union 39, 241-248. https://doi. org/10.1029/TR039i002p00241

Kaandorp, V.P., de Louw, P.G.B., van der Velde, Y., Broers, H.P., 2018. Transient groundwater travel time distributions and age-ranked storage-discharge relationships of three lowland catchments. Water Resour. Res. 54, 4519-4536. https://doi.org/10.1029/2017WR022461

Kohl, D.H., Shearer, G.B., Commoner, B., 1971. Fertilizer nitrogen: contribution to nitrate in surface water in a corn belt watershed. Science 174, 1331-1334.

Lewis and Clark Natural Resources District, 2020. https://lcnrd.nebraska.gov/ bazile-gma/unl-demo-sites (Accessed August 31, 2020).

Lindsey, B.D., Loper, C.A., Hainly, R.A., 1997. Nitrate in ground water and stream base flow in the lower Susquehanna River basin, Pennsylvania and Maryland. WaterResour. Investig. Rep. 97-4146. https://doi.org/10.3133/wri974146

Lowrance, R., Dabney, S., Schultz, R., 2002. Improving water and soil quality with conservation buffers. J. Soil Water Conserv. 57, 36A-43A.

Meinardi, C.R., Beusen, A.H.W., Bollen, M.J.S., Klepper, O., Willems, W.J., 1995. Vulnerability to diffuse pollution and average nitrate contamination of European soils and groundwater. Water Sci. Technol. 31, 159-165. https://doi. org/10.1016/0273-1223(95)00368-W

Messer, T.L., Burchell, M.R., Grabow, G.L., Osmond, D.L., 2012. Groundwater nitrate reductions within upstream and downstream sections of a riparian buffer. Ecol. Eng. 47, 297-307. https://doi.org/10.1016/j.ecoleng.2012.06.017 
Miller, M.P., Tesoriero, A.J., Capel, P.D., Pellerin, B., Hyer, K.E., Burns, D., Al, M.E.T., 2016. Stream fate of nitrate using high-frequency water quality data. Water Resour. Bull. 52, 330-347. https://doi.org/10.1002/2015WR017753

Miller, M.P., Tesoriero, A.J., Hood, K., Terziotti, S., Wolock, D.M., 2017. Estimating discharge and nonpoint source nitrate loading to streams from three endmember pathways using high-frequency water quality data. Water Resour. Res. 53, 10201-10216. https://doi.org/10.1002/2017WR021654

Mitsch, W.J., Day, J.W., Wendell Gilliam, J., Groffman, P.M., Hey, D.L., Randall, G.W., Wang, N., 2001. Reducing nitrogen loading to the Gulf of Mexico from the Mississippi River Basin: strategies to counter a persistent ecological problem. Bioscience 51, 373. https://doi.org/10.1641/0006-3568(2001)051[0373:rnlttg] 2.0.co:2

Mittelstet, A.R., Glimore, T.E., Messer, T., Rudnick, D.R., Heartherly, T., 2019. Evaluation of selected watershed characteristics to identify best management practices to reduce Nebraskan nitrate loads from Nebraska to the Mississippi/ Atchafalaya River basin. Agric. Ecosyst. Environ. 277, 1-10. https://doi. org/10.1016/j.agee.2019.02.018

Molenat, J., Gascuel-Odoux, C., Ruiz, L., Gruau, G., 2008. Role of water table dynamics on stream nitrate export and concentration in agricultural headwater catchment (France). J. Hydrol. 348, 363-378. https://doi.org/10.1016/j.jhydrol.2007.10.005

Mueller, D.K., Ruddy, B.C., Battaglin, W.A., 1997. Logistic model of nitrate in streams of the upper-midwestern United States. J. Environ. Qual. 26, 1223-1230. https:// doi.org/10.2134/jeq1997.00472425002600050005x

Nakagaki, N., Wieczorek, M.E., 2016. Estimates of Subsurface Tile Drainage Extent for 12 Midwest States, 2012: U.S. Geological Survey Data Release. https://doi. org/10.5066/F7W37TDP

Nangia, V., Mulla, D.J., Gowda, P.H., 2010. Precipitation changes impact stream discharge, nitrate-nitrogen load more than agricultural management changes. J. Environ. Qual. 39, 2063-2071. https://doi.org/10.2134/jeq2010.0105

Nas, B., Berktay, A., 2010. Groundwater quality mapping in urban groundwater using GIS. Environ. Monit. Assess. 160, 215-227. https://doi.org/10.1007/ s10661-008-0689-4

Nebraska Department of Environment and Energy, 2016. Bazile Groundwater Management Area Plan. http://deq.ne.gov/publica.nsf/pages/16-013

Nebraska Department of Environment and Energy, 2017. Nebraska Fertilizer, Soil Conditioner and Ag Lime Tonnage and Sampling Report, Calendar Year 2017. https://nda.nebraska.gov/plant/fertilizer/2017report.pdf

Nebraska Department of Environment and Energy, 2019. Nebraska Groundwater Quality Monitoring Report. http://dee.ne.gov/publica.nsf/Pubs Wat_Cat.xsp

Niño de Guzmán, G.T., Hapeman, C.J., Prabhakara, K., Codling, E.E., Shelton, D.R., Rice, C.P., Hively, W.D., McCarty, G.W., Lang, M.W., Torrents, A., 2012. Potential Pollutant Sources in a Choptank River (USA) Subwatershed and the Influence of Land Use and Watershed. https://doi.org/10.1016/j.scitotenv.2012.03.056 
Panno, S.V., Kelly, W.R., Hackley, K.C., Hwang, H.H., Martinsek, A.T., 2008. Sources and fate of nitrate in the Illinois River Basin, Illinois. J. Hydrol. 359, 174-188. https:// doi.org/10.1016/j.jhydrol.2008.06.027

Patle, G.T., Sikar, T.T., Rawat, K.S., Singh, S.K., 2019. Estimation of infiltration rate from soil properties using regression model for cultivated land. Geol. Ecol. Landscapes 3, 1-13. https://doi.org/10.1080/24749508.2018.1481633

Patty, L., R'eal, B., Gril, J.J., 1997. The use of grassed buffer strips to remove pesticides, nitrate and soluble phosphorus compounds from runoff water. Pestic. Sci. 49, 243-251. https://doi.org/10.1002/ (SICI)1096-9063(199703)49:3<243::AIDPS510>3.0.C0;2-8

Perez, M., 2017. Water Quality Targeting Success Stories; How to Achieve Measurably Cleaner Water Through U.S. Farm Conservation Watershed Projects. American Farmland Trust and World Resources Institute Report http://www. farmland.org/WaterQualitySuccessStories http://www.wri.org/publication/ water-quality-successstories

Poor, C.J., McDonnell, J.J., 2007. The effects of land use on stream nitrate dynamics. J. Hydrol. 332, 54-68. https://doi.org/10.1016/j.jhydrol.2006.06.022

PRISM Climate Group, 2004. Oregon State University. http://prism.oregonstate.edu

Puckett, L.J., Zamora, C., Essaid, H., Wilson, J.T., Johnson, H.M., Brayton, M.J., Vogel, J. R., 2008. Transport and fate of nitrate at the ground-water/surfacewater interface. J. Environ. Qual. 37, 1034-1050. https://doi.org/10.2134/ jeq2006.0550

R Core Team, 2018. R: A Language and Environment for Statistical Computing. R Foundation for Statistical Computing, Vienna, Austria. http://www.R-project.org/

Rabah, F.K.J., Ghabayen, S.M., Salha, A.A., 2011. Effect of GIS interpolation techniques on the accuracy of the spatial representation of groundwater monitoring data in Gaza Strip. J. Environ. Sci. Technol. 4, 579-589. https://doi.org/10.3923/ jest.2011.579.589

Randall, G.W., Mulla, D.J., 2001. Nitrate nitrogen in surface waters as influenced by climatic conditions and agricultural practices. J. Environ. Qual. 30, 337-344. https://doi.org/10.2134/jeq2001.302337x

Rhoades, M.G., Meza, J.L., Beseler, C.L., Shea, P.J., Kahle, A., Vose, J.M., Eskridge, K.M., Spalding, R.F., 2013. Atrazine and nitrate in public drinking water supplies and non- Hodgkin lymphoma in Nebraska, USA. Environ. Health Insights 7, 15-27. https://doi.org/10.4137/EHI.S10629

Richardson, W.B., Strauss, E.A., Bartsch, L.A., Monroe, E.M., Cavanaugh, J.C., Vingum, L., Soballe, D.M., 2004. Denitrification in the Upper Mississippi River: rates, controls, and contribution to nitrate flux. Can. J. Fish. Aquat. Sci. 61, 1102-1112. https://doi.org/10.1139/F04-062

Royer, T.V., Tank, J.L., David, M.B., 2004. Transport and fate of nitrate in headwater agricultural streams in Illinois. J. Environ. Qual. 33, 1296. https://doi. org/10.2134/jeq2004.1296

Scanlon, B.R., Reedy, R.C., Stonestrom, D.A., Prudic, D.E., Dennehy, K.F., 2005. Impact of land use and land cover change on groundwater recharge and quality in the southwestern US. Glob. Chang. Biol. 11, 1577-1593. https://doi. org/10.1111/j.1365-2486.2005.01026.x 
Schilling, K.E., Libra, R.D., 2000. The relationship of nitrate concentrations in streams to row crop land use in Iowa. J. Environ. Qual. 29, 1846-1851. https://doi. org/10.2134/jeq2000.00472425002900060016x

Schilling, K.E., Wolter, C.F., 2001. Contribution of base flow to nonpoint source pollution loads in an agricultural watershed. Groundwater 39, 49-58. https://doi. org/10.1111/j.1745-6584.2001.tb00350.x

Schipper, L.A., Robertson, W.D., Gold, A.J., Jaynes, D.B., Cameron, S.C., 2010. Denitrifying bioreactors-an approach for reducing nitrate loads to receiving waters. Ecol. Eng. 36, 1532-1543. https://doi.org/10.1016/j.ecoleng.2010.04.008

Shearer, L.A., Goldsmith, J.R., Young, C., Kearns, O.A., Tamplin, B.R., 1972. Methemoglobin levels in infants in an area with high nitrate water supply. Am. J. Public Health 62, 1174-1180. https://doi.org/10.2105/AJPH.62.9.1174

Shukla, S., Saxena, A., 2018. Global status of nitrate contamination in groundwater: its occurrence, health impacts, and mitigation measures. Handb. Environ. Mater. Manag. 869-888. https://doi.org/10.1007/978-3-319-73645-7_20

Smart, M.M., Barney, T.W., Jones, J.R., 1981. Watershed impact on stream water quality: a technique for regional assessment. J. Soil Water Conserv. 36, 297-300.

Soil Survey Staff, 2014. The Gridded Soil Survey Geographic (SSURGO) Database for Nebraska. January 15 (FY2014 official release). United States Department of Agriculture, Natural Resources Conservation Service. https://gdg.sc.egov.usda. gov/

Sonnichsen, K., 2020. City of Creighton Water Commissioner. Personal Communication on May 21, 2020 Regarding Discharge Rates at Water and Wastewater Treatment Plants.

Sorando, R., Comín, F.A., Jim’enez, J.J., Sánchez-P’erez, J.M., Sauvage, S., 2019. Water resources and nitrate discharges in relation to agricultural land uses in an intensively irrigated watershed. Sci. Total Environ. 659, 1293-1306. https://doi. org/10.1016/j.scitotenv.2018.12.023

Steinheimer, T.R., Scoggin, K.D., Kramer, L.A., 1998. Agricultural chemical movement through a field-size watershed in Iowa: subsurface hydrology and distribution of nitrate in groundwater. Environ. Sci. Technol. 32, 1039-1047. https://doi. org/10.1021/es970598j

Stelzer, R.S., Drover, D.R., Eggert, S.L., Muldoon, M.A., 2011. Nitrate retention in a sand plains stream and the importance of groundwater discharge. Biogeochemistry 103, 91-107. https://doi.org/10.1007/s10533-010-9449-y

Stolp, B.J., Solomon, D.K., Suckow, A., Vitvar, T., Rank, D., Aggarwal, P.K., Han, L.F., 2010. Age dating base flow at springs and gaining streams using helium-3 and tritium: Fischa-Dagnitz system, southern Vienna Basin, Austria. Water Resour. Res. 46, 1-13. https://doi.org/10.1029/2009wr008006

Sudduth, E.B., Perakis, S.S., Bernhardt, E.S., 2013. Nitrate in watersheds: straight from soils to streams? J. Geophys. Res. Biogeosci. 118, 291-302. https://doi. org/10.1002/igrg.20030

Temkin, A., Evans, S., Manidis, T., Campbell, C., Naidenko, O.V., 2019. Exposure-based assessment and economic valuation of adverse birth outcomes and cancer risk due to nitrate in United States drinking water. Environ. Res. 176, 108442. https:// doi.org/10.1016/j.envres.2019.04.009 
Tesoriero, A.J., Duff, J.H., Saad, D.A., Spahr, N.E., Wolock, D.M., 2013. Vulnerability of streams to legacy nitrate sources. Environ. Sci. Technol. 47, 3623-3629. https:// doi.org/10.1021/es305026x

United States Environmental Protection Agency, 1993. Method 353.2: Determination of Nitrate-nitrite Nitrogen by Automated Colorimetry. Technical Report EPA/600/R- 93/100.

University of Nebraska-Lincoln, 2000. Quality-assessed Agrichemical Contaminant Database for Nebraska Ground Water. https://clearinghouse.nebraska.gov

Van Meter, K.J., Basu, N.B., 2017. Time lags in watershed-scale nutrient transport: an exploration of dominant controls. Environ. Res. Lett. 12 https://doi. org/10.1088/1748-9326/aa7bf4

Vega, C.P., Mårtensson, E.M., Wideqvist, U., Kaiser, J., Zieger, P., Ström, J., 2019. Composition, isotopic fingerprint and source attribution of nitrate deposition from rain and fog at a Sub-Arctic Mountain site in Central Sweden (Mt Åreskutan). Tellus, Ser. B Chem. Phys. Meteorol. 71, 1-19. https://doi.org/10.1080/16000889 .2018 .1559398

Wang, S., Zheng, W., Currell, M., Yang, Y., Zhao, H., Lv, M., 2017. Relationship between land-use and sources and fate of nitrate in groundwater in a typical recharge area of the North China Plain. Sci. Total Environ. 609, 607-620. https://doi. org/10.1016/j.scitotenv.2017.07.176

Ward, M.H., Jones, R.R., Brender, J.D., de Kok, T.M., Weyer, P.J., Nolan, B.T., Villanueva, C.M., van Breda, S.G., 2018. Drinking water nitrate and human health: an updated review. Int. J. Environ. Res. Public Health 15, 1-31. https://doi.org/10.3390/ ijerph15071557

Williams, M.R., King, K.W., Fausey, N.R., 2015. Contribution of tile drains to basin discharge and nitrogen export in a headwater agricultural watershed. Agric. Water Manage. 158, 42-50. https://doi.org/10.1016/j.agwat.2015.04.009

Wolock, D.M., 2003. Base-flow Index Grid for the Conterminous United States. U.S. Geological Survey Open-File Report 03-263. https://water.usgs.gov/lookup/ getspatial?bfi48grd

Yamada, T., Logsdon, S.D., Tomer, M.D., Burkart, M.R., 2007. Groundwater nitrate following installation of a vegetated riparian buffer. Sci. Total Environ. 385, $297-$ 309. https://doi.org/10.1016/j.scitotenv.2007.06.035

Yang, P., Li, Y., Groves, C., Hong, A., 2019. Coupled hydrogeochemical evaluation of a vulnerable karst aquifer impacted by septic effluent in a protected natural area. Sci. Total Environ. 658, 1475-1484. https://doi.org/10.1016/j. scitotenv.2018.12.172

Young, E.O., Briggs, R.D., 2005. Shallow ground water nitrate-N and ammonium-N in cropland and riparian buffers. Agric. Ecosyst. Environ. 109, 297-309. https://doi. org/10.1016/j.agee.2005.02.026 